\title{
Ozonized Water in Microbial Control: Analysis of the Stability, In Vitro Biocidal Potential, and Cytotoxicity
}

\author{
Laerte Marlon Conceição dos Santos ${ }^{1}$, Eduardo Santos da Silva ${ }^{1}$ (1) , Fabricia Oliveira Oliveira ${ }^{1}$, \\ Leticia de Alencar Pereira Rodrigues ${ }^{1}$, Paulo Roberto Freitas Neves ${ }^{2}$, Cássio Santana Meira ${ }^{1}$, \\ Greta Almeida Fernandes Moreira ${ }^{1}$, Gabriela Monteiro Lobato ${ }^{3}$, Carlos Nascimento ${ }^{3}$, Marcelo Gerhardt ${ }^{3}$, \\ Arlene Souza Lessa ${ }^{4}$, Luis Alberto Breda Mascarenhas ${ }^{1}$ and Bruna Aparecida Souza Machado ${ }^{1, *} \mathbb{0}$
}

1 University Center SENAI/CIMATEC, SENAI Institute of Innovation in Health Advanced Systems (ISI SAS), Salvador 41650-010, Bahia, Brazil; laerte.santos@fbter.org.br (L.M.C.d.S.); eduardossilva06@gmail.com (E.S.d.S.); fabricia.oliveira@fbter.org.br (F.O.O.); leticiap@fieb.org.br (L.d.A.P.R.); cassio.meira@fieb.org.br (C.S.M.); greta.moreira@fieb.org.br (G.A.F.M.); breda@fieb.org.br (L.A.B.M.)

2 University Center SENAI/CIMATEC, SENAI Computational Modeling and Industrial Technology, Salvador 41650-010, Bahia, Brazil; paulo.neves@fieb.org.br

3 China Three Gorges Corporation-CTG Brazil, Rio Paraná Energia S.A. Rodovia MS-444 s/n $\mathrm{n}^{\circ} \mathrm{km} 58$, Ilha Solteira 79590-000, Selviria, Brazil; gabriela.lobato@ctgbr.com.br (G.M.L.); carlos.nascimento@ctgbr.com.br (C.N.); marcelo.gerhardt@ctgbr.com.br (M.G.)

4 Gonçalo Moniz Institute, FIOCRUZ Microscopy Service, Technological Platforms Network Salvador 40296-710, Bahia, Brazil; arlene.lessa@fiocruz.br

check for

updates

Citation: Santos, L.M.C.d.; Silva, E.S.d.; Oliveira, F.O.; Rodrigues, L.d.A.P.; Neves, P.R.F.; Meira, C.S.; Moreira, G.A.F.; Lobato, G.M.; Nascimento, C.; Gerhardt, M.; et al. Ozonized Water in Microbial Control: Analysis of the Stability, In Vitro Biocidal Potential, and Cytotoxicity. Biology 2021, 10, 525. https:// doi.org/10.3390/biology10060525

Academic Editor: Katsutoshi Hori

Received: 11 May 2021

Accepted: 10 June 2021

Published: 12 June 2021

Publisher's Note: MDPI stays neutral with regard to jurisdictional claims in published maps and institutional affiliations.

Copyright: (C) 2021 by the authors Licensee MDPI, Basel, Switzerland This article is an open access article distributed under the terms and conditions of the Creative Commons Attribution (CC BY) license (https:// creativecommons.org/licenses/by/ $4.0 /)$.
* Correspondence: brunam@fieb.org.br

Simple Summary: Controlling microbial infections, especially nosocomial infection, is a task that continues to be a burden in many societies. The current pandemic has brought new concerns on this matter, mainly on how to better control the dissemination of microbial agents in the environment/surfaces and among humans. Therefore, the search for alternative methods and agents for disinfection is warranted. The aim of our study was to analyze the disinfecting potential of ozonized water in different in vitro tests. By performing microbiological and cell lineage in vitro assays, the biocidal effect of ozonized water was confirmed. Upon a short incubation time, bacterial strains and a yeast were killed by ozonized water, whereas there was no cytotoxicity in the mammalian cell line. These findings lead to the conclusion this agent can be safely tested in technologies for water spray disinfection devices.

Abstract: $\mathrm{O}_{3}$ dissolved in water (or ozonized water) has been considered a potent antimicrobial agent, and this study aimed to test this through microbiological and in vitro assays. The stability of $\mathrm{O}_{3}$ was accessed following modifications of the physicochemical parameters of water, such as the temperature and $\mathrm{pH}$, with or without buffering. Three concentrations of $\mathrm{O}_{3}(0.4,0.6$, and $0.8 \mathrm{ppm})$ dissolved in water were tested against different microorganisms, and an analysis of the cytotoxic effects was also conducted using the human ear fibroblast cell line (Hfib). Under the physicochemical conditions of $4{ }^{\circ} \mathrm{C}$ and $\mathrm{pH} 5, \mathrm{O}_{3}$ remained the most stable and concentrated compared to $\mathrm{pH} 7$ and water at $25^{\circ} \mathrm{C}$. Exposure to ozonized water resulted in high mortality rates for Escherichia coli, Pseudomonas aeruginosa, Staphylococcus aureus, Enterococcus faecalis, and Candida albicans. Scanning electron micrograph images indicate that the effects on osmotic stability due to cell wall lysis might be one of the killing mechanisms of ozonized water. The biocidal agent was biocompatible and presented no cytotoxic effect against Hfib cells. Therefore, due to its cytocompatibility and biocidal action, ozonized water can be considered a viable alternative for microbial control, being possible, for example, its use in disinfection processes.

Keywords: aqueous ozone; antimicrobial; antimicrobial resistance; sanitizer; cytotoxicity 


\section{Introduction}

Ozone $\left(\mathrm{O}_{3}\right)$ is a gas that has a natural configuration of three oxygen atoms. It is considered an elemental form of oxygen that occurs naturally in the Earth's atmosphere, protecting the Earth from harmful solar ultraviolet radiation [1]. $\mathrm{O}_{3}$ is naturally produced by the irradiation of sunlight and the action of compounds, such as nitrogen oxides and volatile organic compounds [1]. $\mathrm{O}_{3}$ can also be produced artificially by the use of electricity generators [2,3], in which both air and oxygen can be used for gas formation. Its formation occurs from oxygen $\left(\mathrm{O}_{2}\right)$ atoms that are supplied by the separation of the $\mathrm{O}_{2}$ molecules through the application of electrical discharges [2]. The free atom of $\mathrm{O}_{2}$ quickly combines with an available molecule of $\mathrm{O}_{2}\left(\mathrm{O}+\mathrm{O}_{2}>\mathrm{O}_{3}\right)$ forming $\mathrm{O}_{3}$ [2,4]. Once formed, the $\mathrm{O}_{3}$ rapidly decomposes into $\mathrm{O}_{2}(\mathrm{t} 1 / 2=20 / 30 \mathrm{~min})$, and, for this reason, it must be produced in the place where it will be used [2,5].

As more antimicrobials are becoming ineffective to drug-resistant microorganisms, the focus should be shifted to alternative therapies. Research into new and non-antibiotic approaches to overcome infectious disease should be the focus of high priority research and development projects [6-10]. In addition, a search for methodologies aimed at reducing the spread and transmission rate for these pathogens, through contact either between humans or between humans and environments/surfaces, is warranted [11].

In several adapted in vitro sensitivity assays, the biocidal effect of $\mathrm{O}_{3}$ gas was confirmed, leading to a reduction in the load of bacteria, such as Escherichia coli, Bacillus cereus, Pseudomonas aeruginosa, Staphylococcus aureus, and Bacillus cereus (as well as B. anthracis and B. subtilis), among others [3,4,12-14]. This effect was also observed in species of fungi $[15,16]$, such as the filamentous Aspergillus brasiliensis and the yeast Candida albicans [17]. Additionally, the antiviral activity of $\mathrm{O}_{3}$ was confirmed in Murine Norovirus (MNV-1), Bacteriophages, Hepatitis A Virus (HAV), and Polyvirus type 1 [18-20].

A problem associated with $\mathrm{O}_{3}$ gas is its toxicity [21,22]. One way to minimize this effect is its use dissolved in water. Given the toxicity of $\mathrm{O}_{3}$ and due to its reasonable solubility in water, increasing attention has been given to the use of this gas as a sanitizing agent $[11,23] . \mathrm{O}_{3}$ solubility in water indeed allows its immediate reaction with any soluble compounds and biomolecules present in biological fluids [23,24].

The generation of $\mathrm{O}_{3}$ in water (or other aqueous medium) occurs using $\mathrm{O}_{3}$ generators based on the dielectric barrier discharge method, also known as the corona effect [2]. This type of discharge is produced by applying a high voltage between two parallel electrodes, having between them a dielectric and a free space through which the air flows. Some systems perform this transformation from the ambient air, while others are coupled to high purity $\mathrm{O}_{2}$ cylinders. The air is bubbled directly into the water through an air outlet. After this ozonation process, it is necessary to perform the quantification and determination of the dissolved $\mathrm{O}_{3}$ concentration [25-27].

$\mathrm{O}_{3}$ dissolved in water (or ozonized water) can be defined as water obtained after an $\mathrm{O}_{3}$ infusion by the ozonation process. During this process, the only chemical reactions that can occur are those between $\mathrm{O}_{3}$ and inorganic matter, organic matter, or biological materials that are available, emphasizing that there is no reaction with the pure water itself $[25,26]$. Some parameters of evaluation and maintenance of the stability of ozonized water are important for this process of production and use, such as the $\mathrm{pH}$ and temperature, these being among other important factors for the half-life of the gas dissolved in water [26,28].

Among the advantages presented by ozonized water is the reduction of gas toxicity without the loss of the $\mathrm{O}_{3}$ sanitizing action. Experimental studies have proven the effectiveness of ozonized water as a microbicide agent. This feature is related to its powerful oxidizing action occurring from its decomposition process $\left(\mathrm{O}_{(3)} \leftrightharpoons \mathrm{O}+\mathrm{O}_{(2)}\right)$, with the release of free radicals capable of acting in the inactivation of bacteria, fungi, viruses, and protozoans $[12,15,16,19,27,29,30]$. The biocidal action can also be identified by the direct form of action of this agent under the organic compounds of these microorganisms, affecting, in turn, their metabolisms [27,29]. 
Considering the need for new strategies for the control of microbial infections, the use of sanitizing agents, such as ozonized water, can be considered a safe strategy, even in emergencies, such as the current pandemic [11]. Therefore, the objective of this study was to evaluate the $\mathrm{O}_{3}$ stability in water under different $\mathrm{pH}$ and temperature conditions. In addition, the antimicrobial potential of ozonized water and its cytotoxic effects on mammalian cells were evaluated.

\section{Materials and Methods}

Our experimental design is summarized in Figure 1. Details are given in the following sections.

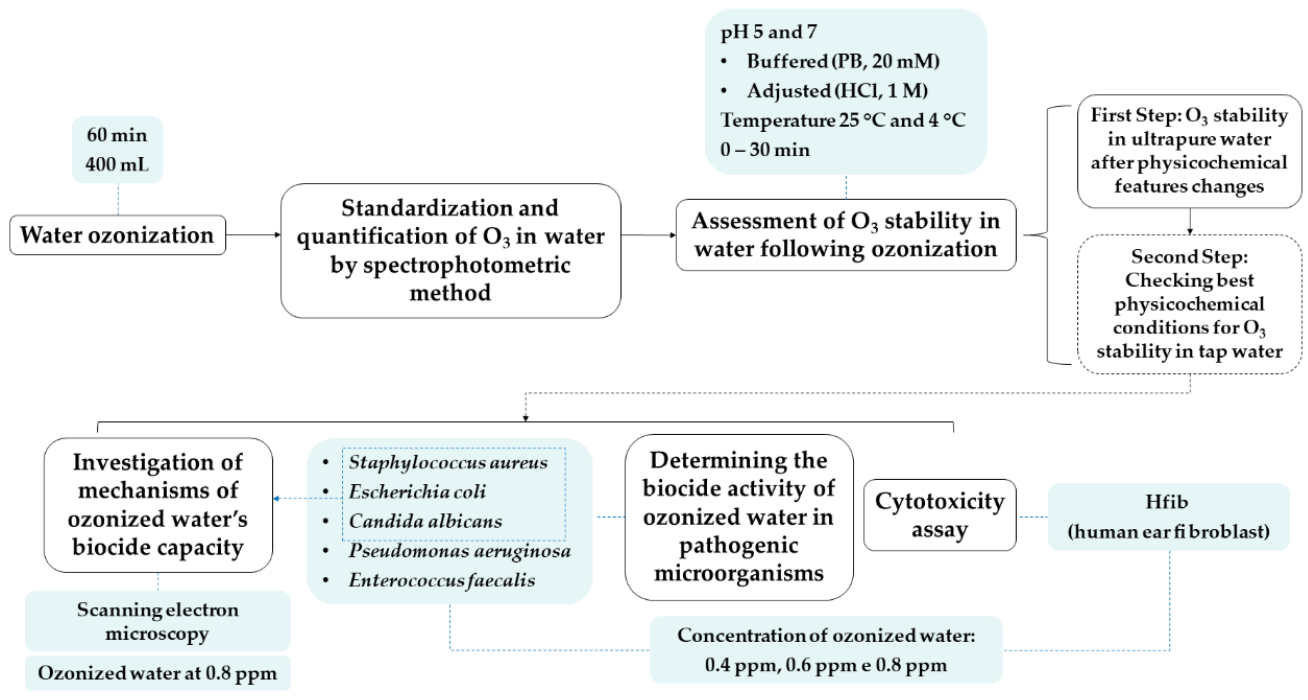

Figure 1. Experimental design. Synthesis of the methodology applied in this study.

\subsection{Water Ozonation}

$\mathrm{O}_{3}$ was dissolved in water using three jointly Ozonic $\mathrm{C} 2$ generators (Ozonic, Brazil, Indústria de Equipamentos de Ozônio Ltda, São Paulo, Brazil) for 60 min. This type of generator bubbles $2 \mathrm{~g}$ of $\mathrm{O}_{3}$ per hour, using ambient air as a feed gas captured through a $2 \mathrm{~L} /$ min compressor. The equipment displayed a flow rate of $0.9 \mathrm{~L} / \mathrm{min}$, and a rotameter was used for measurements. For all ozonation processes detailed herein, we used $400 \mathrm{~mL}$ of either ultrapure water (Merck, Darmstadt, Germany) or tap water. Either type of water was placed in a glass beaker covered with Parafilm ${ }^{\circledR}$ M (Sigma-Aldrich, Saint Louis, MI, USA).

\subsection{Standardization and Quantification of $\mathrm{O}_{3}$ in Water Using the Spectrophotometric Method}

A spectrophotometric method for the quantification of aqueous $\mathrm{O}_{3}$ was standardized, based on a previously published method [31]. This iodometric method involves the oxidation of an iodine buffered solution and spectrophotometric measurements of the triiodide ion released by $\mathrm{O}_{3}$ [31]. Initially, the following solutions were prepared: (a) standard solution of potassium iodide (KI, $40 \mathrm{mM})$ andiodine $(5 \mathrm{mM})$; and (b) reaction solution, containing potassium dihydrogen phosphate $\left(\mathrm{KH}_{2} \mathrm{PO}_{4}, 100 \mathrm{mM}\right)$, disodium hydrogen phosphate $\left(\mathrm{Na}_{2} \mathrm{HPO}_{4}, 100 \mathrm{mM}\right)$, and $2 \% \mathrm{KI}$. This reaction solution is used for the detection of high amounts of aqueous $\mathrm{O}_{3}$ [31].

Two calibration curves were prepared. In this case, the standard solution was diluted in the reaction solution producing concentrations from 0.015 to $8 \mathrm{ppm}$ (parts per million). Each point was read immediately after the dilution of the standard solution at a wavelength absorbance of $352 \mathrm{~nm}$ (Spectrophotometer Model UV-M51 UV-Visible, BEL Photonics ${ }^{\circledR}$, Monza, Italy). The assay was repeated for reproducibility purposes, but fewer concentration points were needed to achieve a valid standard curve. The absorbance values were then plotted using GraphPad Prism version 8.4.3 (686) for Windows (GraphPad Software, San 
Diego, CA, USA, www.graphpad.com, accessed on 25 March 2021). The curves were fitted in the software by choosing simple linear regression. As shown in Figure S1, the similarity of the calibration curves as well as the high $\mathrm{R}$ square indicate the validity of the generated curves and the reproducibility of the method.

For the detection of $\mathrm{O}_{3}$ in water, samples of ozonized water were incubated with the reaction solution (1:1) and allowed to react for $30 \mathrm{~min}$. The incubation was performed in a dark chamber at $4{ }^{\circ} \mathrm{C}$. The reaction solution was used as a blank. A Spectroquant ${ }^{\circledR}$ Ozone Test kit 100607 (Merck, Darmstadt, Germany) was used to confirm the concentrations determined by the standardized method.

\subsection{Assessment of $\mathrm{O}_{3}$ Stability in Water Following Ozonation}

\subsubsection{First Step: $\mathrm{O}_{3}$ Stability in Ultrapure Water after Physicochemical Feature Changes}

Considering the previous data on the stability of $\mathrm{O}_{3}$ in ultrapure water, which was previously considered the best type of water for increased $\mathrm{O}_{3}$ stability [26,32], changes were applied in its physicochemical parameters. Samples of ultrapure water with these different physicochemical characteristics are displayed in Table S1, and the changes are related to the temperature and $\mathrm{pH}$. Regarding the temperature, water was kept in a fridge until it achieved a temperature of $4{ }^{\circ} \mathrm{C}$, which was checked using a thermometer (K29-7070, Kasvi, Sao Jose dos Pinhais, PR, Brazil).

For $\mathrm{pH}$-adjustment evaluations, hydrochloric acid $(\mathrm{HCl}) 1 \mathrm{M}$ was used to adjust the $\mathrm{pH}$, which was verified using a $\mathrm{pH}$ meter (Mettler Toledo FiveEasy ${ }^{\mathrm{TM}}$ Plus, Merck Darmstadt, Germany). Additionally, buffering was tested as a potential condition for stability by using sodium phosphate (PB) buffer $(20 \mathrm{mM})$ with $\mathrm{pH} 5$ or 7 . The aim of these changes was to define which of these physicochemical parameters would maintain $\mathrm{O}_{3}$ longer in the water. After $1 \mathrm{~h}$ of ozonation for each test (Table S1) and considering the end of this process as the primary point of stability, aliquots of ozonized water were collected at $0,5,10,15,20$, and $30 \mathrm{~min}$, and determination of the concentration was performed as mentioned in the Section "Standardization and quantification of $\mathrm{O}_{3}$ in water using the spectrophotometric method".

Considering $0 \mathrm{~min}$ as reference, the percentage of $\mathrm{O}_{3}$ reduction in water was calculated in all tested conditions (Table S1) and for each time of the stability curve. The calculation was performed using the formula $\% \mathrm{R}=[(\mathrm{A}-\mathrm{B}) / \mathrm{A}] * 100$, with $\mathrm{A}$ the amount in ppm of ozone dissolved in water at time 0 and $\mathrm{B}$ the amount of ozone dissolved in water after the study time. In the cases of certain tests, an ice bath was used to keep low temperatures in the glass beakers. The $\mathrm{pH}$ and temperature were checked before and after the ozonation processes. The experiment was in duplicate and repeated once. The data were then plotted using GraphPad Prism.

\subsubsection{Second Step: Checking Best Physicochemical Conditions for $\mathrm{O}_{3}$ Stability in Tap Water}

Due to its easy obtainment and help in reducing costs during the development of ozonized water technologies, tests in tap water were also performed, applying the best physicochemical conditions found in the stability experiments using ultrapure water. Given the results with ultrapure water, only pH 5 (adjusted or buffered) was evaluated at different temperatures, which is shown in Table S2. The ozonizing and quantification practices were the same as those described above. However, considering that there was still detectable $\mathrm{O}_{3}$ in the tests with ultrapure water after $30 \mathrm{~min}$, we added more points to the stability curve, with the following time points: 40,50, and $60 \mathrm{~min}$. The experiment was performed in duplicate and repeated once. The data were then plotted using GraphPad Prism.

\subsection{Determining the Biocidal Activity of Ozonized Water in Pathogenic Microorganisms}

The bacterial strains Staphylococcus aureus (ATCC 6538), Escherichia coli (ATCC 25922), Pseudomonas aeruginosa (ATCC 27853), and Enterococcus faecalis (ATCC 29212) were cultivated on tryptone soy agar (TSA) for $18-24 \mathrm{~h}$ at $37^{\circ} \mathrm{C}$. The yeast Candida albicans (ATCC 
18804) was grown on Sabouraud chloramphenicol agar (SCA) for $48 \mathrm{~h}$ at $30^{\circ} \mathrm{C}$. After TSA or SCA growth, at least three well-isolated colonies were selected and transferred with an inoculation loop into a tube, which contained $5 \mathrm{~mL}$ of saline $(0.85 \% \mathrm{NaCl})$. The turbidity of the broth culture was adjusted to obtain an optical turbidity comparable to that of the McFarland 0.5 standard solution, which contains approximately $1-2 \times 10^{8} \mathrm{CFU} \mathrm{mL}^{-1}$ of E. coli ATCC 25922. Then, the microorganisms were diluted in saline to obtain concentrations of $5 \times 10^{5}, 5 \times 10^{4}$, and $5 \times 10^{3} \mathrm{CFU} \mathrm{mL}^{-1}$.

Based on previous studies and the unique characteristics of $\mathrm{O}_{3}$ reactions [33,34], the concentrations of $0.8,0.6$, and $0.4 \mathrm{ppm}$ of $\mathrm{O}_{3}$ dissolved in tap water were tested in the assay, whose best water physicochemical features were used as follows: non-buffering, a temperature of $4{ }^{\circ} \mathrm{C}$, and a pH 5 adjustment with $\mathrm{HCl}$. Briefly, $1 \mathrm{~mL}$ of inoculum was incubated with $4.0 \mathrm{~mL}$ of ozonized water in the three concentrations of dissolved $\mathrm{O}_{3}$. The incubation time of these samples was $1 \mathrm{~min}$ at $20{ }^{\circ} \mathrm{C}$. Following this interval, $0.5 \mathrm{~mL}$ of the inoculum, under the action of the different concentrations of $\mathrm{O}_{3}$ in the ozonized water, were added to $4.5 \mathrm{~mL}$ of a neutralizer (PB buffer $\mathrm{pH} 7,20 \mathrm{mM}$, with $5 \mathrm{~g} / \mathrm{L}$ sodium thiosulfate).

A control without exposure to ozonized water was performed for each dilution, although this control went through the same dilution process as the tests. Then, the samples were inoculated in duplicate in PCA (plate count agar) for bacteria and SCA for the yeast, which were grown at 37 and $30{ }^{\circ} \mathrm{C}$ for 24 and $48 \mathrm{~h}$, respectively. The number of colonies on each agar plate was calculated after this incubation. Using the mean values of these counts, the death rate was calculated according to the following formula: Death rate $(\%)=(C F U$ of the control - CFU of the test)/CFU of the control) [13]. Additionally, the logarithmic scale $\left(\log _{10}\right)$ reduction factor was calculated using the formula $R F=\log _{10}(A)-\log _{10}(B)$ (where $\mathrm{A}$ is the number of colonies recovered from the unexposed (control) and $\mathrm{B}$ is the number of colonies recovered from the exposed (test) to $\mathrm{O}_{3}$ ) [35]. The data were then plotted using GraphPad Prism.

\subsection{Analysis of Microbials' Morpho-Structural Changes Using Scanning Electron Microscopy}

Scanning electron microscopy (SEM) was used to infer possible mechanisms of the killing capacity of ozonized tap water. In this case, to represent bacteria with distinctive cell walls and morphologies, one Gram-positive (S. aureus) and one Gram-negative bacteria (E. coli) were randomly included in this verification, as well as one yeast (C. albicans) of the present study. The turbidity of the broth culture was adjusted to obtain inoculums comparable to that of the McFarland 2 standard solution. The triplicated samples of the cells were centrifuged at $4000 \times g, 20 \mathrm{~min}$, at room temperature.

The pellets were then resuspended in $100 \mu \mathrm{L}$ of saline and incubated with $400 \mu \mathrm{L}$ of ozonized water containing $0.8 \mathrm{ppm}$ of $\mathrm{O}_{3}$. Following $1 \mathrm{~min}$ of incubation, a neutralizer (PB buffer $\mathrm{pH}$ 7, $20 \mathrm{mM}$ with $5 \mathrm{~g} / \mathrm{L}$ sodium thiosulfate) was used. A control without exposure to ozonized water was also performed and went through the same incubations and dilutions as the tests. Following another centrifugation, the microbial pellets were washed using saline and centrifuged again.

For SEM visualizations, the microorganisms in the pellets were fixed sequentially in two fixatives: (i) $2.5 \%$ glutaraldehyde in $0.1 \mathrm{M}$ sodium cacodylate buffer, $\mathrm{pH} 7.4$, for $1-2 \mathrm{~h}$, followed by three washes with the same buffer; and (ii) $1 \%$ osmium tetroxide in $0.1 \mathrm{M}$ sodium cacodylate for $1 \mathrm{~h}$ at room temperature, and washed three times with distilled water. Following fixation, they were then dehydrated in increasing concentrations of ethanol (30\%, 50\%, 70\%, 90\%, and absolute alcohol) and dried to the critical point using a drying machine with liquid $\mathrm{CO}_{2}$ as the transitional medium. The specimens were then examined by a JEOL, JSM-6390LV SEM.

\subsection{Cytotoxicity Assay}

The cell line Hfib (human ear fibroblast) was used for the cytotoxicity assays and obtained as previously stated [36]. The cells were cultivated in RPMI 1640 medium (SigmaAldrich, St. Louis, MO, USA) supplemented with 10\% fetal bovine serum (FBS; GIBCO) 
and $50 \mu \mathrm{g} \mathrm{mL} \mathrm{m}^{-1}$ of gentamicin (Life, Carlsbad, CA, USA) at $37^{\circ} \mathrm{C}$ and $5 \%$ of $\mathrm{CO}_{2}$. To confirm that the cell line was free of mycoplasma, this pathogenic microorganism was detected using the Mycoplasma Stain Kit (Sigma-Aldrich, St. Louis, MO, USA).

The cytotoxicity assay followed the method described by Colombo et al. [37] with certain modifications. Cells were plated in 96-well plates at $5 \times 10^{4}$ cells $\mathrm{mL}^{-1}$ and incubated for $24 \mathrm{~h}$ at $37^{\circ} \mathrm{C}$ and $5 \% \mathrm{CO}_{2}$. Following that, the media was removed, and the cell lines were exposed to ozonized water $(0.4,0.6$, and $0.8 \mathrm{ppm})$, using the best water physicochemical conditions (non-buffering, temperature of $4{ }^{\circ} \mathrm{C}$, and $\mathrm{pH} 5$ adjustment with $\mathrm{HCl}$ ), for $1 \mathrm{~min}$. After this incubation, the ozonized water was removed from the wells, which were washed with saline solution twice. Then, $20 \mu \mathrm{L}$ of medium plus $10 \%$ AlamarBlue (Thermo Fisher Scientific, Carlsbad, CA, USA) were added in the wells. Incubations were followed for $4 \mathrm{~h}$ at $37^{\circ} \mathrm{C}$, and absorbance measurements were carried out at $\lambda=570 \mathrm{~nm}$ and $\lambda=600 \mathrm{~nm}$.

The percentage of cell viability of exposed cells was calculated considering the absorbance of the control cells (without $\mathrm{O}_{3}$ exposure) as $100 \%$. Then, using this value as a reference, we calculated the percentage for the exposed cells. Cell cultures containing $10 \%$ Triton X-100 were used as a positive control. The data were then plotted using GraphPad Prism. The same software was used for statistical analyses. The Kolmogorov-Smirnov test was used to verify the data distribution. Considering the non-parametric distribution, the Kruskal-Wallis test with Dunn's post test was used to access statistical differences among the exposures. * represents $p<0.0001$.

\section{Results and discussion}

\section{1. $\mathrm{O}_{3}$ stability in Water}

Figure 2 details the decay of the concentration (left y-axis) and the percentage of $\mathrm{O}_{3}$ reduction (left y-axis) in ultrapure water for $30 \mathrm{~min}$ and under several physicochemical conditions (Table S1). In fact, the concentration of $\mathrm{O}_{3}$ in water decays depending on the physicochemical state of the water. From Conditions $1 \mathrm{~A}$ and $2 \mathrm{~A}$ ( $\mathrm{pH} 5$ and 7, respectively, at $25^{\circ} \mathrm{C}$ ) to Conditions $3 \mathrm{~A}$ and $4 \mathrm{~A}$ ( $\mathrm{pH} 5$ and 7, respectively, at $4{ }^{\circ} \mathrm{C}$ ) (Table S1 and Figure $\left.2 \mathrm{~A}, \mathrm{~B}\right), \mathrm{O}_{3}$ did not fall to $100 \%$. The decrease in $\mathrm{pH}$ and temperature was clearly positive in terms of increasing the initial concentration of $\mathrm{O}_{3}$ in the water as well as decreasing the percentage of reduction. Specifically, when the temperature was decreased, the initial concentration increased from $0.571 \pm 0.198$ to $1.045 \pm 0.021 \mathrm{ppm}$ in ultrapure water with the $\mathrm{pH}$ adjusted to 7 and 4 , respectively.

In addition, $\mathrm{O}_{3}$ took longer to decay at low temperatures, either at acidic or neutral $\mathrm{pH}$. However, at $\mathrm{pH} 5$, the concentration was always higher at any of the times on the stability curve (Figure 2B). We estimate that, at $\mathrm{pH} 5$ and $4{ }^{\circ} \mathrm{C}$, the concentration of approximately $0.3 \mathrm{ppm}$ was maintained for about $30 \mathrm{~min}$. This effect of $\mathrm{pH}$ on the slower decay of the $\mathrm{O}_{3}$ concentration in water was also observed in ozonized water at room temperature (Figure 2A), despite lower concentrations. The ultrapure water samples from Tests 2A $\left(\mathrm{pH} 7\right.$ at $25^{\circ} \mathrm{C}$ ) and $4 \mathrm{~A}\left(\mathrm{pH} 7\right.$ at $\left.4{ }^{\circ} \mathrm{C}\right)$ (Table S1), initially adjusted to $\mathrm{pH} 7$, displayed a reduction in $\mathrm{pH}$ at the end of bubbling, to 3.7 and 5, respectively.

Regarding buffering, the profile of the stability curves from Tests $5 \mathrm{~B}$ and $6 \mathrm{~B}(\mathrm{pH} 5$ and 7 , respectively, at $25^{\circ} \mathrm{C}$ ) to Tests $7 \mathrm{~B}$ and $8 \mathrm{~B}\left(\mathrm{pH} 5\right.$ and 7 , respectively, at $4{ }^{\circ} \mathrm{C}$ ) (Table S1) was not similar to the results with the samples with $\mathrm{pH}$ adjusted with $\mathrm{HCl}$, but it was with regard to $\mathrm{pH} 5$ at $4{ }^{\circ} \mathrm{C}$ (Figure $2 \mathrm{C}, \mathrm{D}$ ). However, the concentrations and percentages of reduction decreased and increased, respectively, in comparison with the same conditions in the adjusted $\mathrm{pH}$ of ultrapure water. We observed that, when using the $20 \mathrm{mM}$ PB buffer, $\mathrm{O}_{3}$ was not detected after $5 \mathrm{~min}$ in Condition $6 \mathrm{~B}\left(\mathrm{pH} 7\right.$ at $25^{\circ} \mathrm{C}$ ) (Table $\mathrm{S} 1$ and Figure $2 \mathrm{C}$ ). Despite this, we confirmed that cooling helped to increase the concentration and stability of $\mathrm{O}_{3}$ in ultrapure water, and this was more evident at $\mathrm{pH} 5$.

At $\mathrm{pH}$, after an initial drop after $5 \mathrm{~min}$, the concentration of aqueous $\mathrm{O}_{3}$ remained virtually constant for $30 \mathrm{~min}$ (Figure 2D) in buffered ultrapure water, as it was for the water with $\mathrm{pH}$ adjusted with $\mathrm{HCl}$ (Figure 2B). In terms of concentration, while there was 
almost no increase in the concentration at $\mathrm{pH} 7$ in both temperatures, in buffered water with $\mathrm{pH} 5$, the concentration increased from $0.269 \pm 0.112$ to $0.695 \pm 0.262 \mathrm{ppm}$ at 25 and $4{ }^{\circ} \mathrm{C}$, respectively. Comparing the four stability curves, buffering did not display effects on increasing the solubility of $\mathrm{O}_{3}$ in water.

A

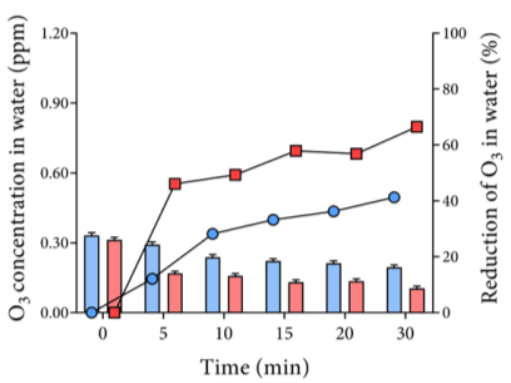

$\mathrm{C}$

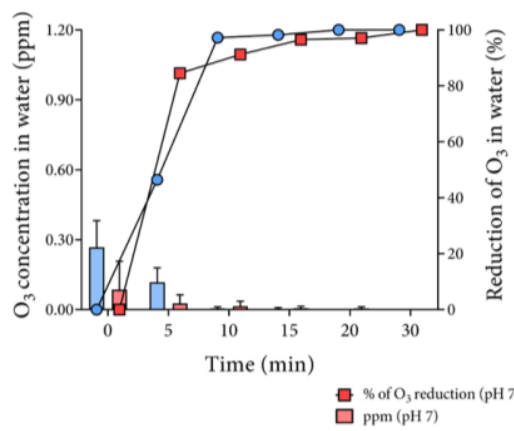

B

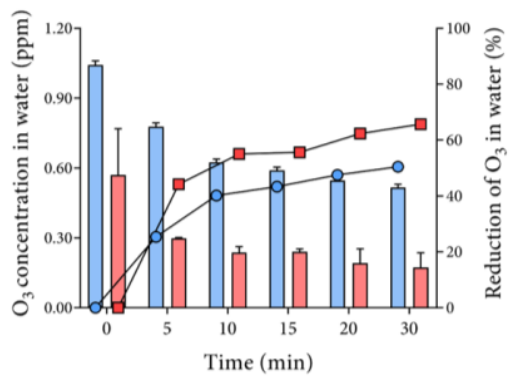

$\mathrm{D}$

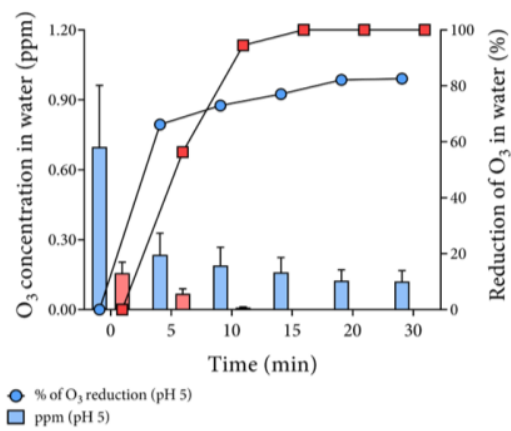

Figure 2. Ozone stability curves in ultrapure water. Ozonation of non-buffered ultrapure water at $25^{\circ} \mathrm{C}(\mathbf{A})$ and $4{ }^{\circ} \mathrm{C}(\mathbf{B})$. The left $\mathrm{y}$-axis is fitted the mean with standard deviation for the concentration in parts per million (ppm). The right $\mathrm{y}$-axis is fitted the percentage of the $\mathrm{O}_{3}$ reduction in water. Both displayed $y$-axes were obtained from the same experiment. The percentage of $\mathrm{O}_{3}$ reduction in water was calculated considering the first sample $(0 \mathrm{~min})$ as the basis. Adjustment of $\mathrm{pH}$ was performed with $1 \mathrm{M} \mathrm{HCl}$. Ozonation of buffered (PB, $20 \mathrm{mM})$ ultrapure water at $25^{\circ} \mathrm{C}(\mathrm{C})$ and $4{ }^{\circ} \mathrm{C}(\mathrm{D})$.

This finding was confirmed at both temperatures; however, the difference in the stability curves at $25^{\circ} \mathrm{C}$ was striking at both $\mathrm{pH}$ values with buffering inducing a complete decay of $\mathrm{O}_{3}$ in $10 \mathrm{~min}$ (Figure $2 \mathrm{C}$ ), whereas adjustment of the $\mathrm{pH}$ with $\mathrm{O}_{3}$ was still seen in the water after $30 \mathrm{~min}$ (Figure 2A). This behavior was less drastic at $4{ }^{\circ} \mathrm{C}$ given that there was still an $\mathrm{O}_{3}$ presence in the buffered water at $\mathrm{pH} 5$ (Figure 2D). In contrast, at $\mathrm{pH} 7, \mathrm{O}_{3}$ was not detected after $10 \mathrm{~min}$ (Figure 2D). Considering that, under the adjustment conditions, there was a fluctuation of $\mathrm{pH}$ in ultrapure water, at either 25 or $4{ }^{\circ} \mathrm{C}$ (something that did not occur in buffered ultrapure waters), our findings indicate that non-buffering can lead to an increase in the $\mathrm{O}_{3}$ solubility in water.

Bearing in mind that $\mathrm{pH} 5$ appeared to be a key chemical parameter and the fact that tap water is known for its several organic compounds, which can reduce the $\mathrm{O}_{3}$ solubility and stability in water, we only tested this $\mathrm{pH}$ in two temperatures. Analyzing the results plotted in Figure 3, we noted that not only did a reduction in temperature increase the concentration of $\mathrm{O}_{3}$ in tap water (Figure $3 \mathrm{~A}$ ), but also the percentage of reduction in $\mathrm{O}_{3}$ in this water was slightly lower at $4{ }^{\circ} \mathrm{C}$ in comparison with $25^{\circ} \mathrm{C}$ (Figure $3 \mathrm{~A}$ ). As with ultrapure water, the buffering clearly reduced the concentration and stability of $\mathrm{O}_{3}$ (Figure 3B). In comparison with ultrapure water, the buffering of tap water was more drastic as $\mathrm{O}_{3}$ was absent in the water after $5 \mathrm{~min}$ at either 25 or $4{ }^{\circ} \mathrm{C}$.

When comparing the two conditions, at $4{ }^{\circ} \mathrm{C}$, the $\mathrm{pH}$-adjusted water maintained the $\mathrm{O}_{3}$ concentration between 0.65 and $0.25 \mathrm{ppm}$ for $60 \mathrm{~min}$, while, in the buffered water, the initial concentration of approximately $0.25 \mathrm{ppm}$ decreased by about $70 \%$ in $5 \mathrm{~min}$ 
(Figures $3 \mathrm{~A}$ and $4 \mathrm{~B}$ ). At $25^{\circ} \mathrm{C}$, the outcomes were similar regarding both the percentage of reduction and concentration, but with lower values of concentration, which were almost not detected in the buffered samples (Figure 3A,B).

A

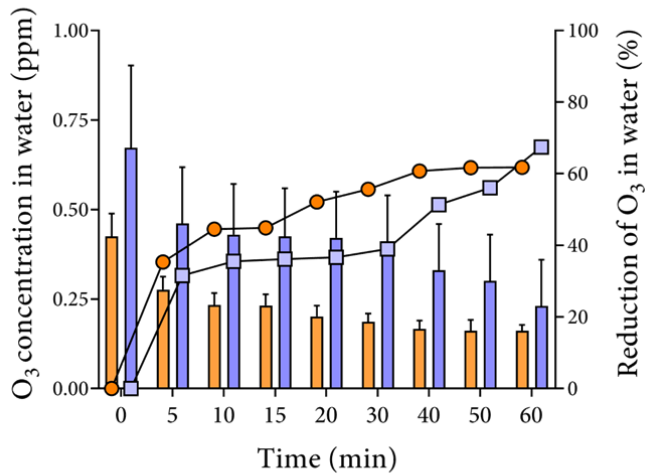

$\square$ \% of $\mathrm{O}_{3}$ reduction
$\square \mathrm{ppm}\left(4^{\circ} \mathrm{C}\right)$
B

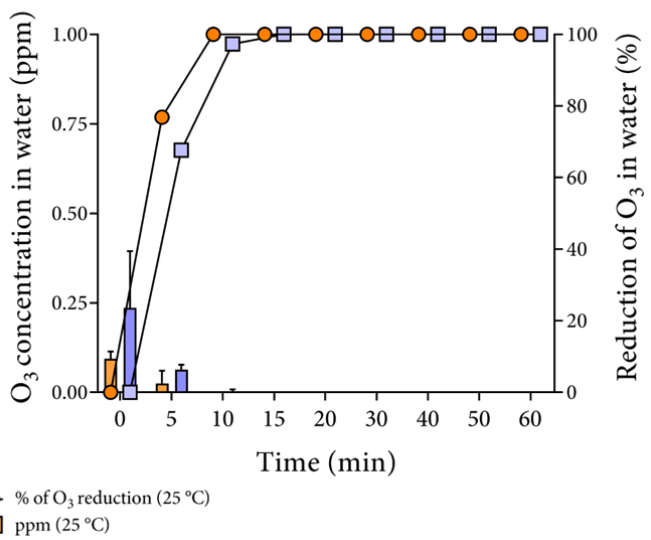

Figure 3. Sixty-minute ozone stability in tap water. Ozonation of non-buffered (A) and buffered (B) tap water. The left y-axis is fitted the mean with standard deviation for the concentration in parts per million (ppm). The right y-axis is fitted the percentage of the $\mathrm{O}_{3}$ reduction in water. Both displayed y-axes were obtained from the same experiment. The percentage of $\mathrm{O}_{3}$ reduction in water was calculated considering the first sample $(0 \mathrm{~min})$ as the basis. Adjustments of the $\mathrm{pH}$ and buffering were performed with $1 \mathrm{M} \mathrm{HCl}$ and $20 \mathrm{mM} \mathrm{PB}$, respectively.

A

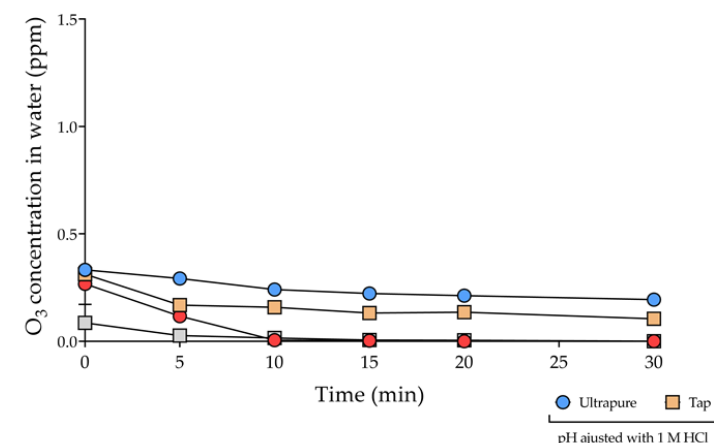

C

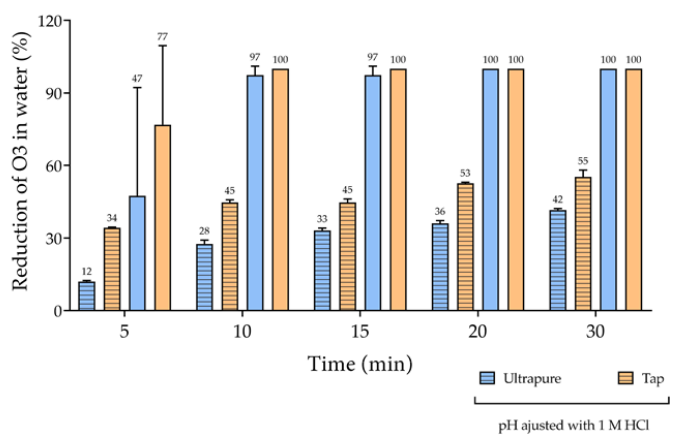

B

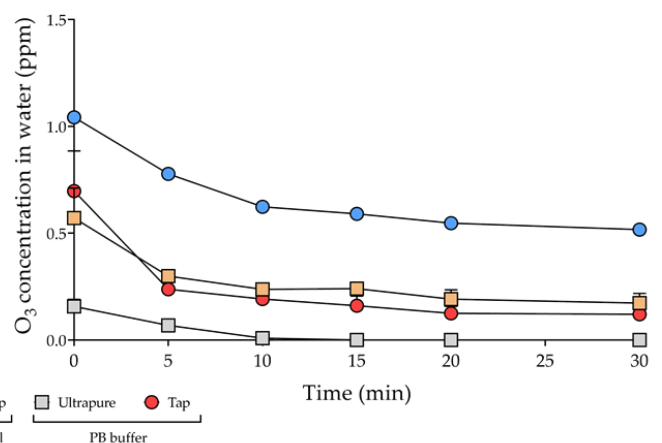

D

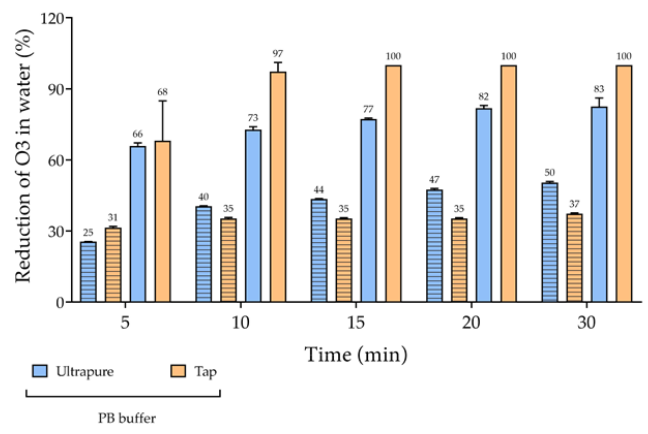

Figure 4. Comparisons of $\mathrm{O}_{3}$ concentration and stability in ultrapure and tap waters at $\mathrm{pH}$ 5. Ozonation of the two types of water at $25^{\circ} \mathrm{C}(\mathrm{A})$ and $4{ }^{\circ} \mathrm{C}$ (B). The mean with standard deviation for the concentration in parts per million (ppm) were used to calculate the percentage of $\mathrm{O}_{3}$ reduction, considering the first sample $(0 \mathrm{~min})$ as the basis. The percentage values were then plotted as graphs for (C) $25^{\circ} \mathrm{C}$ and (D) $4{ }^{\circ} \mathrm{C}$. Adjustments of the $\mathrm{pH}$ and buffering were performed with $1 \mathrm{M} \mathrm{HCl}$ and $20 \mathrm{mM}$ PB buffer, respectively. 
As shown in Figure 4A,B, when comparing the $\mathrm{O}_{3}$ concentrations of the two types of water in $30 \mathrm{~min}$, it is apparent that the physicochemical parameters influenced the concentration of $\mathrm{O}_{3}$. The concentration of dissolved $\mathrm{O}_{3}$ was higher in ultrapure water after $1 \mathrm{~h}$ of ozonation, with initial concentrations of $1.045 \pm 0.021$ and $0.332 \pm 0.011 \mathrm{ppm}$ in water at temperatures of 4 and $25^{\circ} \mathrm{C}$, respectively. In contrast, the concentration of $\mathrm{O}_{3}$ in tap water remained lower than ultrapure water only at $4{ }^{\circ} \mathrm{C}$, with initial concentrations of $\mathrm{O}_{3}$ of $0.673 \pm 0.230 \mathrm{ppm}$ (Figure $4 \mathrm{~A}$ and Table S3). Comparing the $\mathrm{O}_{3}$ concentration in the two types of water with the addition of buffer solution, the ultrapure buffered water contained more dissolved $\mathrm{O}_{3}$ in relation to the buffered tap water. In numbers, at $4{ }^{\circ} \mathrm{C}$, the initial concentrations were $0.695 \pm 0.262 \mathrm{ppm}$ for ultrapure and $0.237 \pm 0.160 \mathrm{ppm}$ for tap, while, at $25{ }^{\circ} \mathrm{C}$, they were $0.269 \pm 0.112 \mathrm{ppm}$ for ultrapure and $0.094 \pm 0.020 \mathrm{ppm}$ for tap (Figure 4B and Table S3).

Figure $4 \mathrm{C}, \mathrm{D}$ displays the comparative results of the percentage of $\mathrm{O}_{3}$ reduction in two types of water. $\mathrm{O}_{3}$ was more stable in tap water at $4{ }^{\circ} \mathrm{C}$ in comparison with ultrapure water at almost all time points of the stability curve, with the exception of $5 \mathrm{~min}$. On the other hand, at $25^{\circ} \mathrm{C}$, the stability of $\mathrm{O}_{3}$ in ultrapure water was higher compared to tap water at all evaluated times in the stability curve. These outcomes indicate that lower temperatures were more important for stability than the purity of the water (Figure 4C and Table S4). The $\mathrm{O}_{3}$ reduction was clearly higher in buffered tap water, with $100 \%$ loss in 15 and $10 \mathrm{~min}$ at temperatures of 4 and $25{ }^{\circ} \mathrm{C}$, respectively. The $\mathrm{O}_{3}$ reduction was also evident in the buffered ultrapure water, with a maximum reduction of $82.73 \%$ at $4{ }^{\circ} \mathrm{C}$ and $100 \%$ after $20 \mathrm{~min}$ in water at $25^{\circ} \mathrm{C}$ (Figure $4 \mathrm{D}$ and Table S4).

These findings confirm that reducing the temperature and $\mathrm{pH}$ can help in $\mathrm{O}_{3}$ stability, even in the buffering condition that appeared to lack stability. Henry's Law defines the solubility of $\mathrm{O}_{3}$, where a given temperature is linearly proportional to the partial pressure of the gas, when it is present in a solution. This means that the lower is the water temperature, the better is the dissolution of the gas in water [38]. At high temperatures, the rates of decomposition are higher, and, in addition, there is a reduction in the solubility of $\mathrm{O}_{3}$ in water [39].

The reaction of $\mathrm{O}_{3}$ with organic compounds in aqueous solution may occur through direct reaction, or indirectly involving reactions with hydroxyl radicals $\left(\mathrm{OH}^{-}\right)$. This indirect reaction is fundamental to understand another important factor in the fast or slow decomposition of $\mathrm{O}_{3}$ in aqueous media: the $\mathrm{pH}$ levels. The stability of $\mathrm{O}_{3}$ in water decreases when the $\mathrm{pH}$ of the medium increases; when the $\mathrm{pH}$ is higher than 8.0, practically half of the introduced $\mathrm{O}_{3}$ is decomposed into various intermediate forms of oxygen in a period of $10 \mathrm{~min}[5,40]$.

$\mathrm{No}_{3}$ was detected in buffers with $\mathrm{pH} 9.0$ in previous studies, while a greater stability of $\mathrm{O}_{3}$ in solution occurred when the $\mathrm{pH}$ was $5.0[24,41]$, as in the results demonstrated in this study. The concentration of $\mathrm{OH}^{-}$can interfere considerably in the ozonation process as well as the acid-base balance of ozonized water, reflecting directly in the concentration of dissociated/non-dissociated forms present in the medium. However, the mathematical description is not yet well defined in relation to the performance of $\mathrm{OH}^{-}$in the ozonation process and in the acid-base balance [26,32].

In relation to the presence of organic compounds in the water, a lower concentration (but not very significant) of $\mathrm{O}_{3}$ was observed in tap water. The presence of organic matter can cause a severe reduction of $\mathrm{O}_{3}$ in water [42-44], due to the rapid action of this agent with the aqueous compounds. However, it is precisely for this reason that $\mathrm{O}_{3}$ (in its gas form) is widely used in the treatment of wastewater [40,45,46] —-for example, reacting with the dirtiness by the direct action of molecular $\mathrm{O}_{3}$ or by indirect reaction of the radical $\mathrm{OH}^{-}[32,46]$. On the other hand, during comparisons with the two types of water, the stability of $\mathrm{O}_{3}$ in cold tap water was higher than that of the ultrapure water at the same temperature.

A possible explanation for this outcome is because the higher is the amount of solutes in water, the lower is the temperature changes, leading to a longer maintenance of the 
cold temperature $[47,48]$ and, in turn, a slightly higher $\mathrm{O}_{3}$ stability in tap water. The presence of a solute in water makes the liquid state less organized because solutes or ions are freer to move at random. Therefore, the liquid water molecules possibly become more disordered in tap water, taking more energy to decrease this entropy as well as increasing the temperature [47-49]. Although we used an ice bath to keep the temperature as fixed as possible at $4{ }^{\circ} \mathrm{C}$, during the ozonation process, some decreases occurred with values close to $0{ }^{\circ} \mathrm{C}$. Taking this into consideration and the fact that physicochemical water parameters in Brazil are usually associated with the dispersion of a high amount of organic matter in the rivers, especially during rainfall season [50], ions $\left(\mathrm{Ca}^{2+}, \mathrm{K}^{+}\right.$, and $\left.\mathrm{Na}^{+}\right)$commonly encountered in soils are notorious for depressing the freezing point of water $[48,49]$.

Another result, regarding the stability of $\mathrm{O}_{3}$, indicated that the buffering did not positively affect the increase of $\mathrm{O}_{3}$ solubility. This finding was confirmed at $25^{\circ} \mathrm{C}$; however, the difference in the stability curves at $4{ }^{\circ} \mathrm{C}$ was quite marked, especially at $\mathrm{pH}$ 5.0. Considering that, in the adjustment conditions, there was $\mathrm{pH}$ fluctuation (final $\mathrm{pH}$ of 4.0 after the experiments) in the water at either 25 or $4{ }^{\circ} \mathrm{C}$ - something that did not occur in buffered water-this is presented as another indication that non-buffering can lead to an increase of $\mathrm{O}_{3}$ solubility in the water due to $\mathrm{pH}$ fluctuations. If the oscillation is downwards, this can cause a higher permanence of $\mathrm{O}_{3}$ in the water, since the lower is the $\mathrm{pH}$, the greater is the half-life of the gas in the water. A previous report indicated clearly that dissolved substances, either ionic or non-ionic, could affect the solubility of $\mathrm{O}_{3}$ in aqueous solutions, and buffering decreased both the solubility and stability of the gas [51].

\subsection{Biocidal Effect of Ozonized Tap Water}

To evaluate the biocidal action of ozonized water (non-buffering, temperature of $4{ }^{\circ} \mathrm{C}$, and $\mathrm{pH} 5$ adjustment with $\mathrm{HCl}$ ), the mortality rates of each microorganism studied are presented in Figures 5-7. This condition of microbial death represents the effect of exposure of microorganisms for $1 \mathrm{~min}$ to ozonized water in different concentrations.

Figure 5 shows the results for the Gram-negative bacteria evaluated in the study. The exposure of $E$. coli to ozonized water showed a bacterial death rate higher than $95 \%$ from the inoculum concentration of $5 \times 10^{5} \mathrm{CFU} \mathrm{mL}^{-1}$ in the three concentrations tested (0.4, 0.6 , and $0.8 \mathrm{ppm}$ ). Better results in relation to $P$. aeruginosa were observed in this study. The mortality rate of the $P$. aeruginosa strain was equal to $100 \%$ from the lowest concentration of ozonized water $(0.4 \mathrm{ppm})$ tested.

The average colony counts for each concentration of ozonized water were calculated and converted to $\log _{10}$. When E. coli was exposed to ozonized water at the inoculum concentration of $5 \times 10^{5} \mathrm{CFU} \mathrm{mL}^{-1}$, a reduction of $>2.23 \log _{10} \mathrm{CFU} \mathrm{mL} \mathrm{m}^{-1}$ was observed. However, at an inoculum concentration equal to or lower than $5 \times 10^{4} \mathrm{CFU} \mathrm{mL}^{-1}$, a higher reduction $\left(>6 \log _{10} \mathrm{CFU} \mathrm{mL} \mathrm{mL}^{-1}\right.$ ) was observed. The logarithmic reduction for P. aeruginosa was higher than the results observed for $E$. coli after the same exposure time at different concentrations of ozonized water.

While Figure 6 shows the results for the Gram-positive bacteria, Figure 7 displays the findings for the evaluated yeast $C$. albicans. Similar to the results demonstrated for the Gram-negative bacteria P. aeruginosa, the mortality rate of the S. aureus and E. faecalis strains were equal to $100 \%$ from the lowest concentration of ozonized water $(0.4 \mathrm{ppm})$ tested. The best biocidal activity was observed against $C$. albicans, with a high death rate at the inoculum concentration of $1.5 \times 10^{8} \mathrm{CFU} \mathrm{mL}{ }^{-1}$. The logarithmic reduction for S. aureus, E. faecalis, and C. albicans proved to be higher than the results with E. coli in the same conditions tested. These results indicate the greater resistance of $E$. coli to treatment with ozonized water when in high inoculum concentrations. 
A

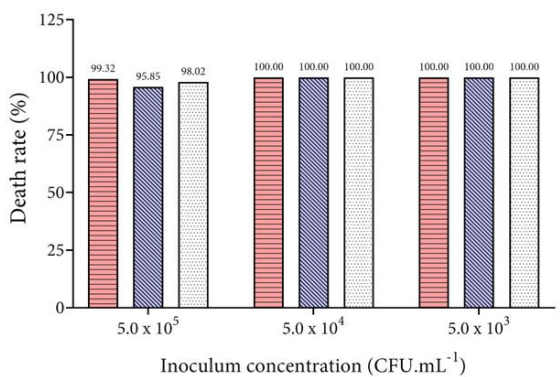

C

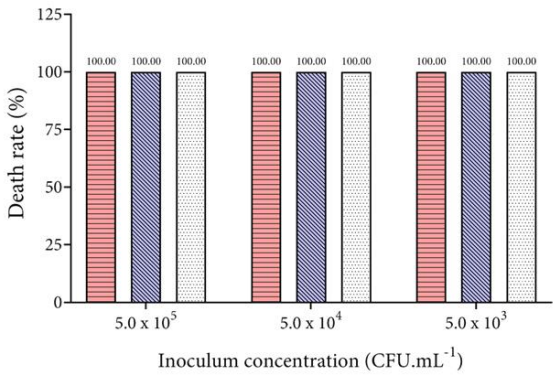

B

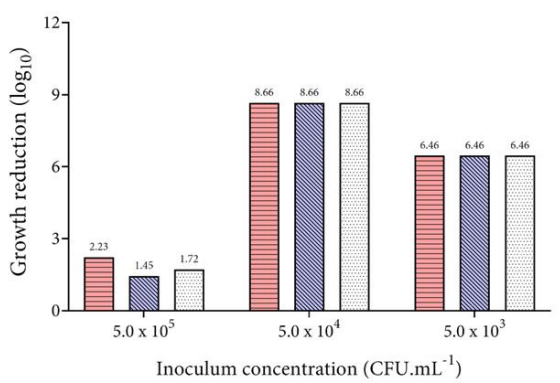

D

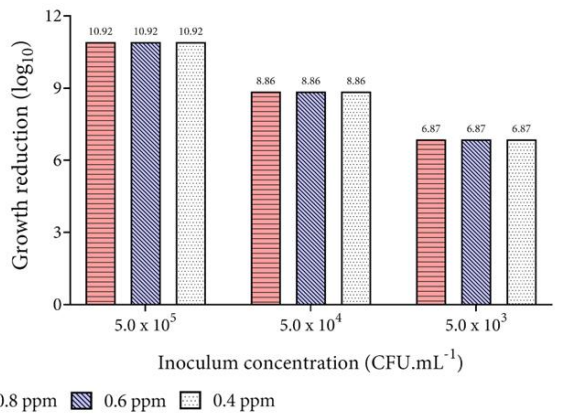

Figure 5. Action of ozonized water on Gram-negative bacteria. Analysis of the percentage of death and growth reduction in $\log _{10}$ for the microorganisms E. coli $(\mathbf{A}, \mathbf{B})$ and P. aeruginosa $(\mathbf{C}, \mathbf{D})$. The concentrations of $0.8,0.6$, and $0.4 \mathrm{ppm}$ of $\mathrm{O}_{3}$ dissolved in tap water were tested, and the number of colonies on each agar plate was calculated after incubation $(1.0 \mathrm{~mL}$ of inoculum and $4.0 \mathrm{~mL}$ of ozonized water at $20^{\circ} \mathrm{C}$ for $1 \mathrm{~min}$ ).

A

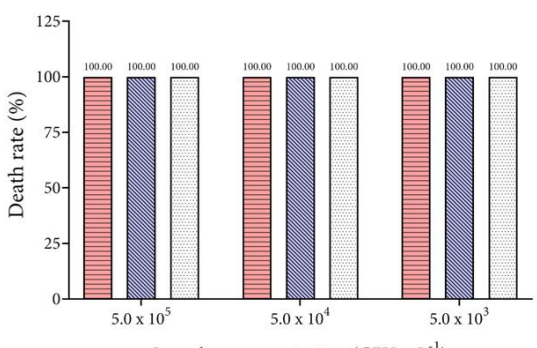

Inoculum concentration (CFU. $\mathrm{mL}^{-1}$ )

C

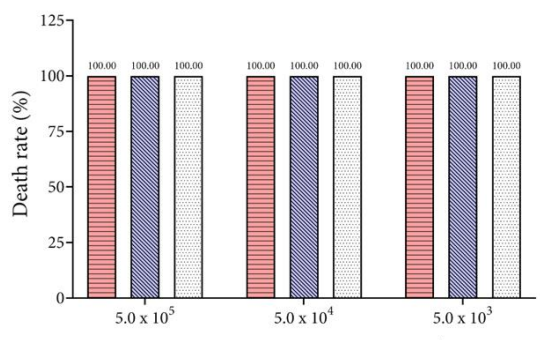

Inoculum concentration (CFU. $\mathrm{mL}^{-1}$ )

$\mathrm{O}_{3}$ concentration in water: $\mathrm{O} 0.8 \mathrm{ppm}$
B

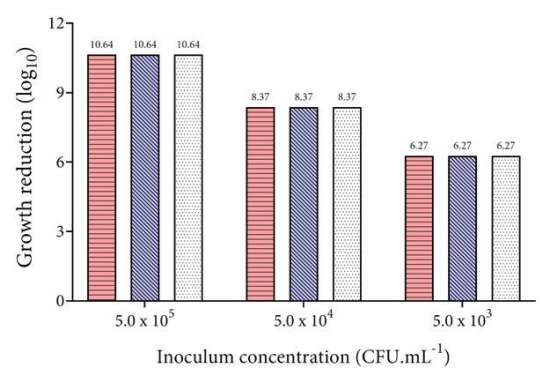

D

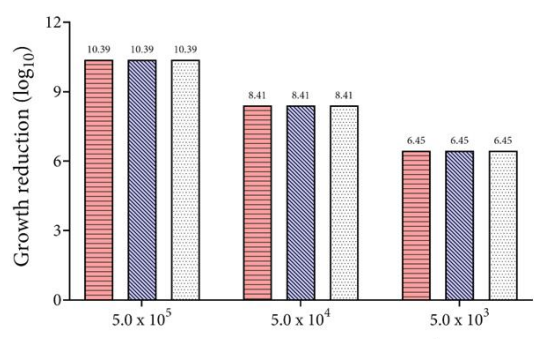

Inoculum concentration (CFU.mL ${ }^{-1}$ )

Figure 6. Action of ozonized water on Gram-positive bacteria. Analysis of the percentage of death and growth reduction in $\log _{10}$ for the microorganisms $S$. aureus $(\mathbf{A}, \mathbf{B})$ and E. faecalis $(\mathbf{C}, \mathbf{D})$. The concentrations of $0.8,0.6$, and $0.4 \mathrm{ppm}$ of $\mathrm{O}_{3}$ dissolved in tap water were tested, and the number of colonies on each agar plate was calculated after incubation $(1.0 \mathrm{~mL}$ of inoculum and $4.0 \mathrm{~mL}$ of ozonized water at $20^{\circ} \mathrm{C}$ for $1 \mathrm{~min}$ ). 
A

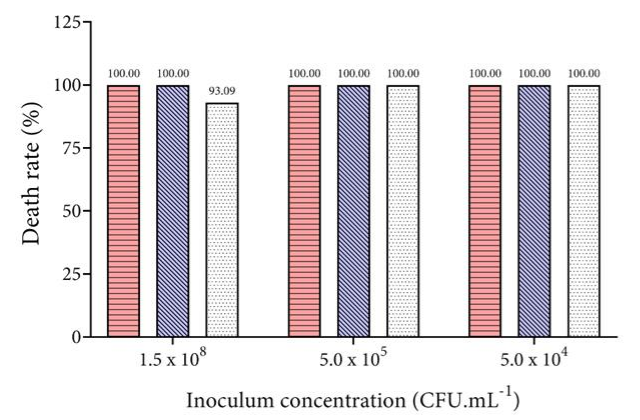

$\mathrm{O}_{3}$ concentration in water: 目 $0.8 \mathrm{ppm}$
B

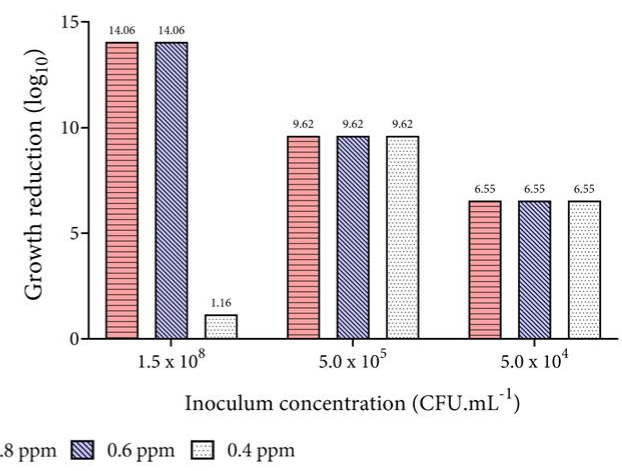

Figure 7. Action of ozonized water on yeast C. albicans. Analysis of the percentage of death (A) and growth reduction in $\log _{10}(\mathbf{B})$ for C. albicans. The concentrations of $0.8,0.6$, and 0.4 ppm of $\mathrm{O}_{3}$ dissolved in tap water were tested, and the number of colonies on each agar plate was calculated after incubation ( $1.0 \mathrm{~mL}$ of inoculum and $4.0 \mathrm{~mL}$ of ozonized water at $20^{\circ} \mathrm{C}$ for $1 \mathrm{~min}$ ).

Although C. albicans suffered growth reduction at the inoculum concentration of $1.5 \times 10^{8} \mathrm{CFU} \mathrm{mL} \mathrm{mL}^{-1}$, all the tested bacteria did not reduce growth as much at this concentration (for this reason, the inoculum concentration of $10^{8}$ for the bacteria was not plotted on the graphs), not allowing colony counting (bacterial confluence in the plaque). However, images of the plates (only bacteria) clearly revealed a microbial reduction following exposure to ozonized water in comparison with the control plates (Figures S3-S5). While in the test plates it was possible to notice isolated colonies, but still impossible to count them, the density of the biomass is clearly so high in the control plates that no isolated colonies can be observed (Figures S3-S5). On the other hand, C. albicans growth was strongly different from the bacteria evaluated in the present study (Figure S6). It is important to emphasize that the greater effect observed of the action of ozonized water in higher concentrations of microorganism inoculum can be explained because the higher is the inoculum, the greater is the colony forming unit in the control. For this reason, $\log _{10}$ is higher at higher concentrations of microorganisms and is lower at lower concentrations. However, to better understand this, it is necessary to evaluate the results of $\log _{10}$ and death rate together, noting that the reduction was mostly $100 \%$, regardless of the inoculum used. The antimicrobial action of $\mathrm{O}_{3}$ herein showed is related to its powerful oxidizing action. $\mathrm{O}_{3}$ has been widely used as an antimicrobial, in both its gaseous and aqueous form, due to its wide range of microbiological, cleaning, and metabolic activities $[6,13,15,16,24,34,45,52,53]$. The antimicrobial action of $\mathrm{O}_{3}$ is related to its powerful oxidizing action. When it decomposes, this gas generates an oxidant reaction by the liberation of reactive oxygen species (ROS), including generating hydroxyl radicals $\left(\mathrm{OH}^{-}\right)$that have a greater oxidative potential $(2.83$ volts) over $\mathrm{O}_{3}$ and both act in the inactivation of several microorganisms $[38,42,46,54,55]$.

In this study, the results show a considerable effectiveness of the ozonized water in the different concentrations of inoculums tested, except for the concentration of $1.5 \times 10^{8} \mathrm{CFU} \mathrm{mL}{ }^{-1}$ in most of the isolates. Megahed et al. [27] observed that the bacterial load is a strong predictor for the reduction of pathogens present in cattle manure exposed to ozonized water. In the study conducted by Białoszewski et al. [14], the concentration of $\mathrm{O}_{3}$ in water capable of eliminating the microorganisms contained in a suspension with a density of $1.5-5.0 \times 10^{8} \mathrm{CFU} \mathrm{mL}^{-1}$ was up to nine times (1.2-3.6 ppm).

These findings were higher than the efficacy of the ozonized water of our study at the same density of microorganism tested. On the other hand, the use of ozonized water ( 0.4 and $8 \mathrm{ppm}$ ) against $E$. coli in an inoculum concentration equal to $3 \times 10^{4} \mathrm{CFU} \mathrm{mL}^{-1}$ was efficient in decontaminating the hands [5]. However, it is important to consider that the number of medically important microorganisms, such as S. aureus, P. mirabilis, Klebsiella spp., and E. coli, present in intact areas of human skin can vary between $10^{2}$ and $10^{6} \mathrm{CFU} / \mathrm{cm}^{2}[56,57]$. 
The susceptibility of microorganisms to $\mathrm{O}_{3}$ varies according to the physiological state of the cells, the $\mathrm{pH}$ of the medium, the temperature, the humidity, and the presence of additives, such as acids, surfactants, and sugars [3,58]. Relatively low concentrations of $\mathrm{O}_{3}$ and a short contact time were sufficient to inactivate pure suspensions of several microorganisms [44,58-60]. In this research, 1 min of exposure followed by the neutralization of $\mathrm{O}_{3}$ in the sodium thiosulfate buffer was effective in microbial reduction in the different concentrations of inoculum tested $[13,58]$. According to the structure of the cell wall, microorganisms can exhibit different sensitivities to ozonized water. In this study, we observed the greatest antimicrobial effect of ozonized water on Gram-positive bacteria [13].

These results are similar to those found by Zhang et al. [61] and Giuliani et al. [24], who, in their studies on the effect of ozonized water on different types of bacteria, reported that the effect of the ozonation process was greater in the action on Gram-positive microorganisms. However, in this work, a similar effect was observed for P. aeruginosa, which is a Gram-negative bacterium. Therefore, it is still necessary to investigate this behavior, taking into consideration the individual characteristics of each microorganism. Factors that can be associated to the distinct presentation of these results are the amount of lipids and lipoprotein present in the cell wall of the microorganisms, as well as the interaction between them and the behavior of the different membrane proteins [55,62].

Moore et al. [63] observed that, after ozonation (2 ppm per 4 h), Gram-negative bacteria (E. coli, S. liquefaciens, and L. innocua) were more sensitive to $\mathrm{O}_{3}$ compared with S. aureus. Białoszewsk et al. [14,33] concluded that all strains of S. aureus, E. coli, E. hirae, and $C$. albicans were rapidly killed in ozonized water with an $\mathrm{O}_{3}$ concentration in the range of 1.3-1.5 ppm during 1 min of exposure. P. aeruginosa ATCC 15442 was less sensitive to the effects of $\mathrm{O}_{3}$, with a decimal logarithm of reduction of 4.97 between the tested concentrations that was close to the limit level required by EN 1040:2006 [64]. The most evident action of ozonized water against C. albicans may be related to the mechanism of action of $\mathrm{O}_{3}$ in fungi through the oxidative mechanism in cell membranes.

The cell walls of fungi are multifaceted and composed of approximately $80 \%$ carbohydrates and $20 \%$ proteins and glycoproteins. The disulfide bonds in the fungal cell wall allow $\mathrm{O}_{3}$ to enter its cytoplasm and alter vital cell functions [65]. Similar results regarding the effectiveness of ozonized water under C. albicans could be observed in other studies. The ozonized water displayed inhibitory effects on the growth and colonization of C. albicans adhered to the surface of acrylic resins for a prosthesis base [66], and there was a reduction in the CFU count of Candida spp. in the saliva of patients with oral candidiasis [67].

Zargaran et al. [68] demonstrated that $\mathrm{O}_{3}$ was effective in controlling the growth of C. albicans and that it acted in the prevention of the formation of germ tubes and decreased the formation of biofilms. $\mathrm{O}_{3}$ acts under fungal species in a similar manner to the effect observed in viruses, promoting modifications to the genetic material $[21,34,55,69]$, and one of the consequences is an increase in the resistance of some isolates to antifungals [68].

Considering the relevant biocidal aspect of ozone shown by our results, ozonized water is a potential sanitizer not only for decontamination of surfaces but as an agent to decrease the spreading of drug-resistant microorganisms in the environment. Some authors have previously stated the possibility of future pandemics, whose pathogenic agents may be bacteria for instance. Therefore, ozonized water can be useful in many spray devices currently available or under construction because it has high biocompatibility and could be used in these methodologies or devices to replace disinfectants considered toxic by regulatory agencies.

\subsection{Microbials' Morpho-Structural Changes Upon Incubation of Ozonized Tap Water}

SEM micrograph visualizations were used to infer possible mechanisms for the observed decreases in the microorganisms' growth. Figure 8 shows that, after exposure to ozonized tap water at $0.8 \mathrm{ppm}$ of $\mathrm{O}_{3}$, morphological and structural changes were observed. For C. albicans, while the non-exposed cells did not display any damage or structural modi- 
fications (Figure 8), the incubation with ozonized water led to severe cell wall disruption as well as a high presence of cell debris (Figure 8).
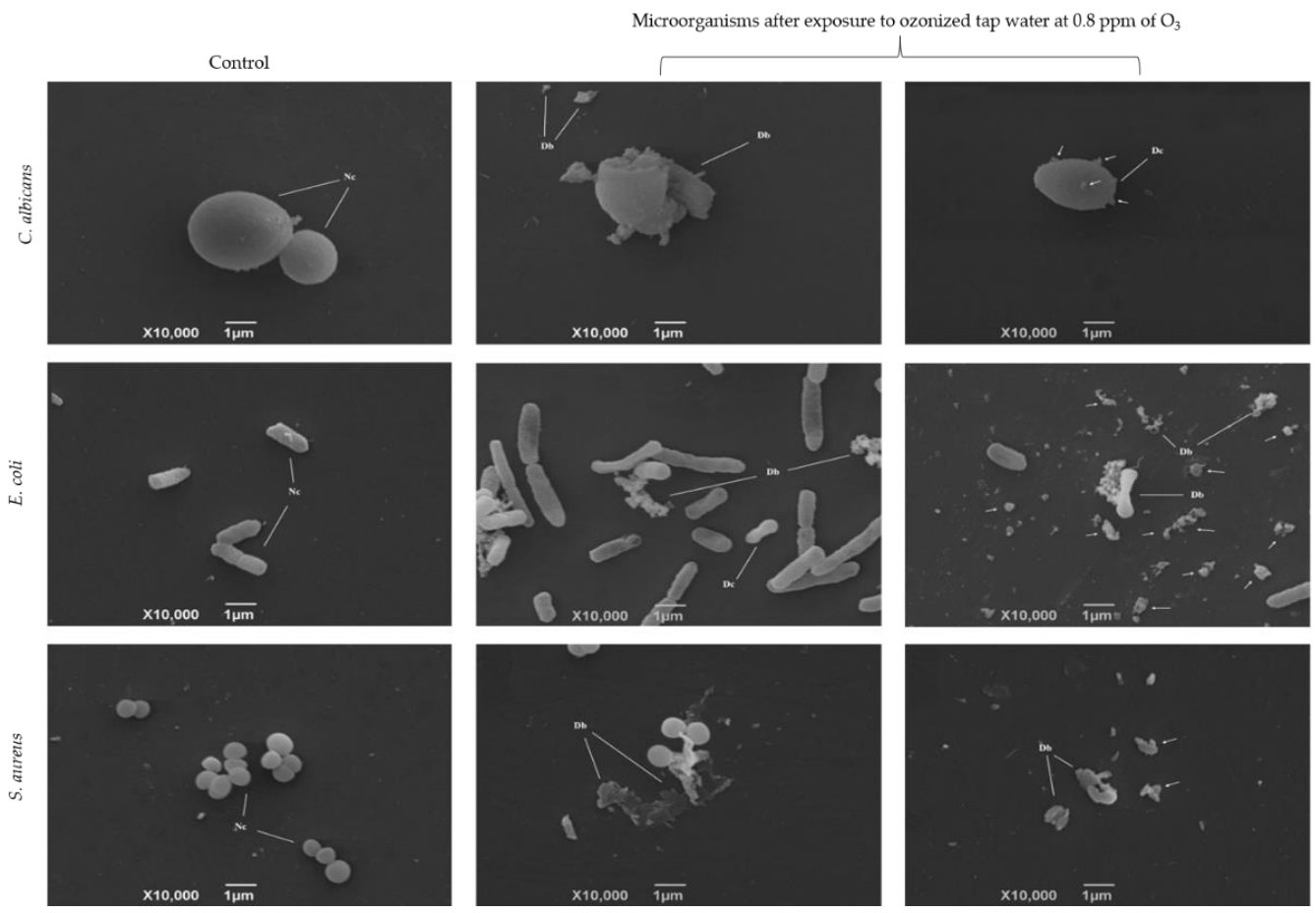

Figure 8. Scanning electron microscopy of C. albicans, E. coli, and S. aureus non-treated or treated with ozonized tap water at $0.8 \mathrm{ppm}$ of $\mathrm{O}_{3}$. Microorganisms used in the test are displayed in left side of the chart. Conditions (control or test) for the assay are shown above. Normal cells (Nc), cell deformity (Dc), and cellular debris (Db) are indicated in the pictures. Arrows were added to the images to highlight other $\mathrm{Db}$ in the slides.

Additionally, the formation of vesicles on C. albicans's cell surface was noticed (Figure 8, arrows), indicating an increase in the permeability of the plasma membrane. In the case of E. coli, in comparing the control (Figure 8) with the exposed bacteria, we found severe cell dissipation (Figure 8), cell wall lysis, and the presence of cell debris (Figure 8, arrows). S. aureus suffered the same damages (Figure 8). These findings indicate that $\mathrm{O}_{3}$, even dissolved in water, not only directly induced damage in the cell walls and plasma membranes but also likely interfered in the cells' osmolality.

Oxygen radicals cause cellular lysis by penetrating the microbial cell membrane in the presence of water, affecting its osmotic stability or interfering with cellular metabolism. However, additional biocidal mechanisms occur from the direct reaction of aqueous $\mathrm{O}_{3}$ with organic compounds of these microorganisms, thus influencing their metabolisms $[17,27,30,70,71]$. The SEM analyses performed in the present study indicate that ozonized tap water may have acted on the plasma membrane and cell walls of two of the bacteria and a yeast tested. The SEM micrographs demonstrated in the results corroborated this type of $\mathrm{O}_{3}$ mechanism of action, which previously inactivated several pathogenic microorganisms [72,73]. Such findings were observed by Thanomsub [72], where $\mathrm{O}_{3}$ inhibited the growth and caused structural changes, such as deformation and cell lysis in E. coli, Salmonella sp., S. aureus, and Bacillus subtilis, after $60 \mathrm{~min}$ of exposure. Clearly, the data found herein underscores the efficacy of $\mathrm{O}_{3}$ as an oxidizer, given the much shorter exposure time used and the achievement of structural damage in most of the E. coli, S. aureus, and C. albicans cells tested in the present research.

The formation of vesicles on the cell surface of $C$. albicans occurred due to the increased permeability of the plasma membrane and may represent the leakage of cellular constituents of cells during exposure to $\mathrm{O}_{3}[3,72,74]$. However, it is important to note 
that cellular inactivation by $\mathrm{O}_{3}$ includes damage to the intracellular components, such as protein oxidation, damage to DNA, and alterations of enzymatic activity that cannot be observed from SEM [75]. Additionally, the presence of normal cells in the SEM images indicates that genes related to oxidative stress, such as SoxR, OxyR, and RpoS, favored the survival of those cells $[54,76]$.

The rising resistance of microbes to the current sanitizers and pharmacological treatments raises concerns for future pandemics and control difficulties for the environmental and human dissemination of these pathogenic and resistant microorganisms. Therefore, the data presented herein indicate that the use of ozonized water in technologies for the disinfection of surfaces, medical instruments, and even humans may be an alternative and reliable approach to delay or stop the spread of microbes, as discussed by a recently published patent prospecting [11]. Ozone therapy has been indeed effective not only in dentistry but also in endocrinology and physical therapy $[24,67,73,77-81]$, leading, in some cases, to the control of microbial infections while treating other illnesses $[53,79,82]$. Even methicillin-resistant $S$. aureus have been killed by $\mathrm{O}_{3}$ dissolved in oil during an experimental model of infected ulcer [53].

As another important example in this context, major world health organizations identified a highly pathogenic yeast Candida auris, which is one of the causes of nosocomial bloodstream infections, leading to outbreaks in several healthcare facilities around the globe, including Brazil, and associated with high mortality rates [83,84]. The control of such dangerous fungi has been difficult due its resistance toward most antifungals and the usual disinfectants used in hospital environments [85,86].

Although a recent study demonstrated C. auris resistance toward low concentrations and low exposure time of gaseous ozone [87], another study concluded a higher efficacy of repeated exposure of aqueous ozone, reducing the contamination of this yeast at a concentration range of $0.9-0.1 \mathrm{ppm}$ [88], which is similar to the optimal concentration of $0.8 \mathrm{ppm}$ in the present study. Considering this and the current efficacious use of dissolved ozone in many therapeutic and disinfecting procedures, ozonized tap water may be efficiently included in technologies for disinfection.

\subsection{Cytotoxicity of Ozonized Tap Water}

Figure 9 shows that the mammalian cell line exposed to any concentration of ozonized water was as viable as non-exposed cells (C-), showing no degradation of cell membranes or release of intracellular content, when visualized in inverted optical microscopy. The exposed cells displayed 100\% cell viability in almost all tested concentrations, with the exception of $0.6 \mathrm{ppm}$, in which one of the replicates achieved $98.02 \%$ viability. This outcome was reflected in the non-significance of Dunn's statistical test with comparisons between exposure of the three concentrations and the non-exposed cells. On the other hand, the positive control (Triton-X), as expected, strongly affected viability, leading to complete death of the cells in a significant manner. These results indicate that 1 min exposure to ozonized water, for this cell line, did not present cytotoxic effects.

Before the application of ozonized water in human disinfection, it is important to verify the possibility of cytotoxic effects of ozonized water in mammalian cells. We tested this parameter and confirmed cytotoxic effects in this mammalian cell line. These findings are corroborated by previous studies, whose outcomes showed that some mammalian cells possess complex antioxidant systems, which do not allow ozonolysis at the cytoplasmic membrane and resist other oxidant properties of $\mathrm{O}_{3}$, even when the gas is dissolved in water or oils $[37,77,89]$.

Not only antioxidant enzymes but also hydro-liposoluble compounds are considered components of the antioxidant systems of certain eukaryotic cells, such as blood cells and lineages cultured in vitro $[77,78,89]$. Additionally, it appears that $\mathrm{O}_{3}$ induces these cells to deliver other biochemical reactions in the mitochondrion. This organelle produces adenosine triphosphate (ATP) as a response to free radicals, and this energy molecule, in 
turn, improves the cell viability, given that it is used as a physiological improvement for the cells $[37,77,89]$.

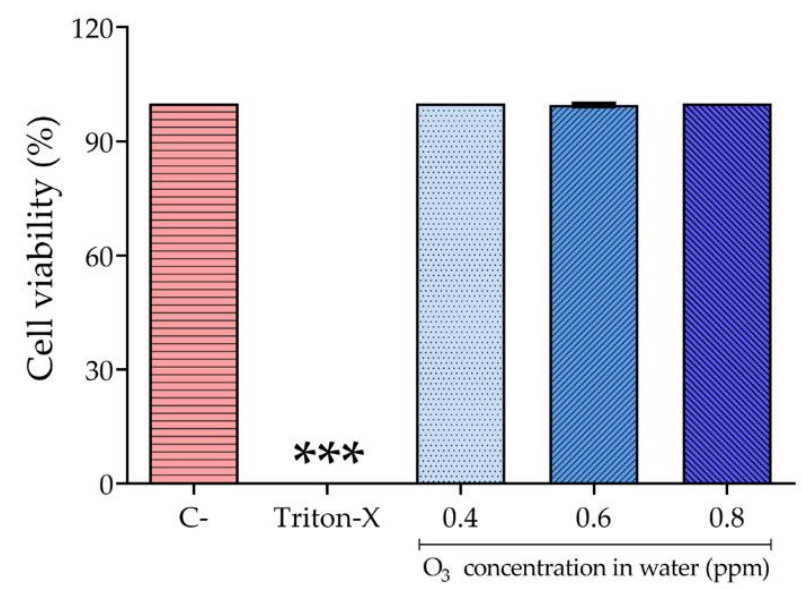

Figure 9. The behavior of Hfib cells upon ozonized water exposure. The different concentrations of ozonized water are displayed in the figure. C- represents the cells that were exposed to the medium only and $10 \%$ Triton-X was used as the positive control (cell death); ${ }^{* * *}$ Statistical difference between the positive control and the different concentrations of ozonated water.

\section{Conclusions}

Given the results exposed, ozonized water is characterized as a potential antimicrobial agent. The $\mathrm{O}_{3}$ concentration increases according to the variation of the temperature and the $\mathrm{pH}$ value of the water. We demonstrated that the higher concentration of $\mathrm{O}_{3}$ in water at $4{ }^{\circ} \mathrm{C}$ and $\mathrm{pH} 5$ resulted in greater efficacy in the decontamination process. In addition, ozonized water with a minimum concentration of $0.6 \mathrm{ppm}$ was sufficient to clearly reduce the number of tested microorganisms, indicating that it can be used as a sanitizing agent. These results were corroborated with the SEM analysis (using ozonized water at $0.8 \mathrm{ppm}$ of $\mathrm{O}_{3}$ ), which indicated that the effects on osmotic stability-due to cell wall lysis-might be one of the killing mechanisms of ozonized water. The ozonized water was also shown to be a biocompatible agent, as it did not present cytotoxic effects in mammalian cells. Therefore, due to its cytocompatibility and biocidal action, ozonized water was considered a viable alternative for microbial control, including for use in disinfection methodologies or devices (even for human use) to replace biocidal agents considered toxic by regulatory agencies.

Supplementary Materials: The following are available online at https:/ / www.mdpi.com/article/ 10.3390/biology10060525/s1, Figure S1: Calibration curves for ozone quantification in water. The assay was performed two times with twenty-three (A) and ten (B) $\mathrm{X}$ values (iodide dilutions) for the detection of aqueous $\mathrm{O}_{3}$, respectively, Figure S2: Representative images of plating Escherichia coli exposed to different $\mathrm{O}_{3}$ concentrations. The concentrations of $0.8,0.6$, and $0.4 \mathrm{ppm}$ of $\mathrm{O}_{3}$ dissolved in tap water were tested and the number of colonies of the agar plate duplicates was calculated after incubation $\left(1.0 \mathrm{~mL}\right.$ of inoculum and $4.0 \mathrm{~mL}$ of ozonized water at $20^{\circ} \mathrm{C}$ for $\left.1 \mathrm{~min}\right)$, Figure S3: Representative images of plating Pseudomonas aeruginosa exposed to different $\mathrm{O}_{3}$ concentrations. The concentrations of $0.8,0.6$, and $0.4 \mathrm{ppm}$ of $\mathrm{O}_{3}$ dissolved in tap water were tested and the number of colonies of the agar plate duplicates was calculated after incubation $(1.0 \mathrm{~mL}$ of inoculum and $4.0 \mathrm{~mL}$ of ozonized water at $20^{\circ} \mathrm{C}$ for $1 \mathrm{~min}$ ), Figure S4: Representative images of plating Staphylococcus aureus exposed to different $\mathrm{O}_{3}$ concentrations. The concentrations of $0.8,0.6$, and 0.4 ppm of $\mathrm{O}_{3}$ dissolved in tap water were tested and the number of colonies of the agar plate duplicates was calculated after incubation $\left(1.0 \mathrm{~mL}\right.$ of inoculum and $4.0 \mathrm{~mL}$ of ozonized water at $20^{\circ} \mathrm{C}$ for $\left.1 \mathrm{~min}\right)$, Figure S5: Representative images of plating Enterococcus faecalis exposed to different $\mathrm{O}_{3}$ concentrations. The concentrations of $0.8,0.6$, and $0.4 \mathrm{ppm}$ of $\mathrm{O}_{3}$ dissolved in tap water were tested and the number of colonies of the agar plate duplicates was calculated after incubation $(1.0 \mathrm{~mL}$ of inoculum and $4.0 \mathrm{~mL}$ of ozonized water at $20^{\circ} \mathrm{C}$ for $1 \mathrm{~min}$ ), Figure S6: Representative images of plating Candida albicans 
exposed to different $\mathrm{O}_{3}$ concentrations. The concentrations of $0.8,0.6$, and 0.4 ppm of $\mathrm{O}_{3}$ dissolved in tap water were tested and the number of colonies of the agar plate duplicates was calculated after incubation $\left(1.0 \mathrm{~mL}\right.$ of inoculum and $4.0 \mathrm{~mL}$ of ozonized water at $20{ }^{\circ} \mathrm{C}$ for $1 \mathrm{~min}$ ), Table S1. Physicochemical changes in ultrapure water to assess ozone stability, Table S2. Physicochemical changes in tap water to assess ozone stability, Table S3. Differences among $\mathrm{O}_{3}$ concentrations in ultrapure and tap waters, Table S4. Comparisons of $\mathrm{O}_{3}$ stability in ultrapure and tap Waters.

Author Contributions: Conceptualization, G.A.F.M., G.M.L., C.N., M.G., L.A.B.M. and B.A.S.M.; Data curation, B.A.S.M.; Formal analysis, L.M.C.d.S., E.S.d.S., F.O.O., L.d.A.P.R., P.R.F.N., C.S.M., A.S.L., L.A.B.M. and B.A.S.M.; Funding acquisition, C.N., M.G. and B.A.S.M.; Investigation, P.R.F.N., G.A.F.M., G.M.L., C.N., L.A.B.M. and B.A.S.M.; Methodology, L.M.C.d.S., E.S.d.S., F.O.O., L.d.A.P.R., P.R.F.N., C.S.M., A.S.L. and B.A.S.M.; Project administration, M.G., L.A.B.M. and B.A.S.M.; Resources, G.A.F.M., G.M.L., C.N., M.G. and L.A.B.M.; Software, L.M.C.d.S., E.S.d.S., F.O.O. and C.S.M.; Supervision, L.d.A.P.R., G.A.F.M., G.M.L., L.A.B.M. and B.A.S.M.; Validation, P.R.F.N.; Visualization, G.A.F.M.; and Writing-original draft, L.M.C.d.S., E.S.d.S., F.O.O., G.M.L., C.N., M.G., L.A.B.M. and B.A.S.M. All authors have read and agreed to the published version of the manuscript.

Funding: This research was funded by China Three Gorges Corporation-CTG BRASIL (Rio Paraná Energia S.A. Rodovia MS-444 s/n ${ }^{\circ} \mathrm{km}$ 58, Ilha Solteira, Selviria-MS), with resources for the ANEEL R\&D Program (PD-10381-0420/2020) and SENAI CIMATEC.

Institutional Review Board Statement: Not applicable.

Informed Consent Statement: Not applicable.

Data Availability Statement: All the results found are available in this manuscript.

Acknowledgments: The authors greatly thank the University Center SENAI/CIMATEC (National Service for Industrial Training-Serviço Nacional de Aprendizagem Industrial)—SENAI CIMATEC (Bahia-Brazil), China Three Gorges Corporation-CTG Brazil (Rio Paraná Energia S.A) and ANEEL (Agência Nacional de Energia Elétrica).

Conflicts of Interest: The authors declare no conflict of interest.

\section{References}

1. Cicerone, R.J. Changes in Stratospheric Ozone. Science 1987, 237, 35-42. [CrossRef] [PubMed]

2. Eliasson, B.; Hirth, M.; Kogelschatz, U. Ozone synthesis from oxygen in dielectric barrier discharges. J. Phys. D Appl. Phys. 1987, 20, 1421-1437. [CrossRef]

3. Scott, D.B.; Lesher, E.C. Effect of Ozone on Survival and Permeability of Escherichia Coli. J. Bacteriol. 1963, 85, 567-576. [CrossRef] [PubMed]

4. Baysan, A.; Beighton, D. Assessment of the Ozone-Mediated Killing of Bacteria in Infected Dentine Associated with Non-Cavitated Occlusal Carious Lesions. Caries Res. 2007, 41, 337-341. [CrossRef]

5. Breidablik, H.; Lysebo, D.; Johannessen, L.; Skare, Å.; Andersen, J.; Kleiven, O. Ozonized water as an alternative to alcohol-based hand disinfection. J. Hosp. Infect. 2019, 102, 419-424. [CrossRef] [PubMed]

6. De Alba, A.M.; Rubio, M.; Morán-Diez, M.; Bernabéu, C.; Hermosa, R.; Monte, E. Microbiological Evaluation of the Disinfecting Potential of UV-C and UV-C Plus Ozone Generating Robots. Microorganisms 2021, 9, 172. [CrossRef]

7. Maurya, D.; Gohil, M.K.; Sonawane, U.; Kumar, D.; Awasthi, A.; Prajapati, A.K.; Kishnani, K.; Srivastava, J.; Age, A.; Pol, R.; et al. Development of Autonomous Advanced Disinfection Tunnel to Tackle External Surface Disinfection of Covid-19 Virus in Public Places. Transact. Indian Natl. Acad. Eng. 2020, 5, 281-287. [CrossRef]

8. Ghosh, C.; Sarkar, P.; Issa, R.; Haldar, J. Alternatives to Conventional Antibiotics in the Era of Antimicrobial Resistance. Trends Microbiol. 2019, 27, 323-338. [CrossRef] [PubMed]

9. Grace, K.; Shukla, M.; Dasgupta, A.; Chopra, S. Alternative Therapies to Antibiotics to Combat Drug-Resistant Bacterial Pathogens. In Antibacterial Drug Discovery to Combat Mdr: Natural Compounds, Nanotechnology and Novel Synthetic Sources; Iqbal, A., Shamim, A., Rumbaugh, K.P., Eds.; Springer: Singapore, 2019; pp. 193-212.

10. Aslam, B.; Wang, W.; Arshad, M.I.; Khurshid, M.; Muzammil, S.; Rasool, M.H.; Nisar, M.A.; Alvi, R.F.; Aslam, M.A.; Qamar, M.U.; et al. Antibiotic resistance: A rundown of a global crisis. Infect. Drug Resist. 2018, 11, 1645-1658. [CrossRef] [PubMed]

11. Mascarenhas, L.A.; Oliveira, F.O.; da Silva, E.S.; dos Santos, L.M.; de Alencar Pereira Rodrigues, L.; Neves, P.R.; Santos, A.Á.; Moreira, G.A.; Lobato, G.M.; Nascimento, C.; et al. Technological Advances in Ozone and Ozonized Water Spray Disinfection Devices. Appl. Sci. 2021, 11, 3081. [CrossRef]

12. Wood, J.P.; Wendling, M.; Richter, W.; Rogers, J. The use of ozone gas for the inactivation of Bacillus anthracis and Bacillus subtilis spores on building materials. PLoS ONE 2020, 15, e0233291. [CrossRef] [PubMed] 
13. Song, M.; Zeng, Q.; Xiang, Y.; Gao, L.; Huang, J.; Huang, J.; Wu, K.; Lu, J. The antibacterial effect of topical ozone on the treatment of MRSA skin infection. Mol. Med. Rep. 2017, 17, 2449-2455. [CrossRef]

14. Białoszewski, D.; Bocian, E.; Bukowska, B.; Czajkowska, M.; Sokół-Leszczyńska, B.; Tyski, S. Antimicrobial activity of ozonated water. Med. Sci. Monit. 2010, 16, 71-75.

15. Akbar, A.; Medina, A.; Magan, N. Potential Control of Mycotoxigenic Fungi and Ochratoxin A in Stored Coffee Using Gaseous Ozone Treatment. Microorganisms 2020, 8, 1462. [CrossRef] [PubMed]

16. Porto, Y.D.; Trombete, F.M.; Freitas-Silva, O.; de Castro, I.M.; Direito, G.M.; Ascheri, J.L.R. Gaseous Ozonation to Reduce Aflatoxins Levels and Microbial Contamination in Corn Grits. Microorganisms 2019, 7, 220. [CrossRef] [PubMed]

17. Hubbezoglu, I.; Zan, R.; Tunç, T.; Sumer, Z.; Hurmuzlu, F. Antifungal Efficacy of Aqueous and Gaseous Ozone in Root Canals Infected by Candida albicans. Jundishapur J. Microbiol. 2013, 6, 8150. [CrossRef]

18. Dubuis, M.-E.; Dumont-Leblond, N.; Laliberté, C.; Veillette, M.; Turgeon, N.; Jean, J.; Duchaine, C. Ozone efficacy for the control of airborne viruses: Bacteriophage and norovirus models. PLoS ONE 2020, 15, e0231164. [CrossRef]

19. Jiang, H.J.; Chen, N.; Shen, Z.Q.; Yin, J.; Qiu, Z.G.; Miao, J.; Yang, Z.W.; Shi, D.Y.; Wang, H.R.; Wang, X.W.; et al. Inactivation of Poliovirus by Ozone and the Impact of Ozone on the Viral Genome. Biomed. Environ. Sci. 2019, 32, 324-333. [PubMed]

20. Brié, A.; Boudaud, N.; Mssihid, A.; Loutreul, J.; Bertrand, I.; Gantzer, C. Inactivation of murine norovirus and hepatitis A virus on fresh raspberries by gaseous ozone treatment. Food Microbiol. 2018, 70, 1-6. [CrossRef]

21. Victorin, K. Review of the genotoxicity of ozone. Mutat. Res. Genet. Toxicol. 1992, 277, 221-238. [CrossRef]

22. Gandhi, C.K.; Mikerov, A.N.; Durrani, F.; Umstead, T.M.; Hu, S.; Wang, G.; Phelps, D.S.; Floros, J. Impact of Ozone, Sex, and Gonadal Hormones on Bronchoalveolar Lavage Characteristics and Survival in SP-A KO Mice Infected with Klebsiella pneumoniae. Microorganisms 2020, 8, 1354. [CrossRef]

23. Da Silva, L.M.; Jardim, W.F. Trends and strategies of ozone application in environmental problems. Quím. Nova 2006, 29 , 310-317. [CrossRef]

24. Giuliani, G.; Ricevuti, G.; Galoforo, A.; Franzini, M. Microbiological aspects of ozone: Bactericidal activity and antibiotic/antimicrobial resistance in bacterial strains treated with ozone. Ozone Ther. 2018, 3. [CrossRef]

25. Langlais, B.; Reckhow, D.A.; Brink, D.R.; Awwa Research Foundation; Compagnie Générale des Eaux. Ozone in Water Treatment: Application and Engineering: Cooperative Research Report; Lewis Publishers: Chelsea, MI, USA, 1991.

26. Filho, F.A.L. Ozone application in water sources: Effects of operational parameters and water quality variables on ozone residual profiles and decay rates. Braz. J. Chem. Eng. 2010, 27, 545-554. [CrossRef]

27. Megahed, A.; Aldridge, B.; Lowe, J. The microbial killing capacity of aqueous and gaseous ozone on different surfaces contaminated with dairy cattle manure. PLoS ONE 2018, 13, e0196555. [CrossRef] [PubMed]

28. Martínez-Sánchez, G. Ozonized Water, Background, General Use in Medicine and Preclinic Support. Ozone Therapy Glob. J. 2019, 9, 33-60.

29. United States Environmental Protection Agency. Alternative Disinfectants and Oxidants Guidance Manual; United States Environmental Protection Agency: Washington, DC, USA, 1999; p. 328.

30. Fontes, B.; Heimbecker, A.M.C.; Brito, G.D.S.; Costa, S.F.; van der Heijden, I.M.; Levin, A.S.; Rasslan, S. Effect of low-dose gaseous ozone on pathogenic bacteria. BMC Infect. Dis. 2012, 12, 358. [CrossRef] [PubMed]

31. Shechter, H. Spectrophotometric method for determination of ozone in aqueous solutions. Water Res. 1973, 7, 729-739. [CrossRef]

32. Gardoni, D.; Vailati, A.; Canziani, R. Decay of Ozone in Water: A Review. Ozone Sci. Eng. 2012, 34, 233-242. [CrossRef]

33. Bialoszewski, D.; Pietruczuk-Padzik, A.; Kalicinska, A.; Bocian, E.; Czajkowska, M.; Bukowska, B.; Tyski, S. Activity of ozonated water and ozone against Staphylococcus aureus and Pseudomonas aeruginosa biofilms. Med. Sci. Monit. 2011, 17, BR339-BR344. [CrossRef] [PubMed]

34. Ding, W.; Jin, W.; Cao, S.; Zhou, X.; Wang, C.; Jiang, Q.; Huang, H.; Tu, R.; Han, S.-F.; Wang, Q. Ozone disinfection of chlorine-resistant bacteria in drinking water. Water Res. 2019, 160, 339-349. [CrossRef] [PubMed]

35. De Vries, T.A.; Hamilton, M.A. Estimating the Antimicrobial Log Reduction: Part Quantitative Assays. Quant. Microbiol. 1999, 1, 29-45. [CrossRef]

36. Bastos, T.M.; Russo, H.M.; Moretti, N.S.; Schenkman, S.; Marcourt, L.; Gupta, M.P.; Wolfender, J.-L.; Queiroz, E.F.; Soares, M.B.P. Chemical Constituents of Anacardium occidentale as Inhibitors of Trypanosoma cruzi Sirtuins. Molecules 2019, 24, 1299. [CrossRef] [PubMed]

37. Colombo, M.; Ceci, M.; Felisa, E.; Poggio, C.; Pietrocola, G. Cytotoxicity evaluation of a new ozonized olive oil. Eur. J. Dent. 2018, 12, 585-589. [CrossRef]

38. Khadre, M.; Yousef, A.E.; Kim, J.-G. Microbiological Aspects of Ozone Applications in Food: A Review. J. Food Sci. 2001, 66, 1242-1252. [CrossRef]

39. Di Bernardo, L.; Dantas, A.D. Métodos E Técnicas De Tratamento De Água. Engenharia Sanitaria e Ambiental 2006, $11,107$. [CrossRef]

40. Qingshi, Z.; Cunli, L.; Zhengyu, X. A Study of Contacting Systems in Water and Wastewater Disinfection by Ozone. Mechanism of Ozone Transfer and Inactivation Related to the Contacting Method Selection. Ozone Sci. Eng. 1989, 11, 169-188. [CrossRef]

41. Tjahjanto, R.T.; Wardhani, S.; Brawijaya University. Ozone Determination: A Comparison of Quantitative Analysis Methods. J. Pure Appl. Chem. Res. 2012, 1, 18-25. [CrossRef] 
42. Westerhoff, P.; Aiken, G.; Amy, G.; Debroux, J. Relationships between the structure of natural organic matter and its reactivity towards molecular ozone and hydroxyl radicals. Water Res. 1999, 33, 2265-2276. [CrossRef]

43. Rahman, M.F.; Jasim, S.Y.; Yanful, E.K.; Ndiongue, S.; Borikar, D. Advanced Oxidation Treatment of Drinking Water: Part II. Turbidity, Particles and Organics Removal from Lake Huron Water. Ozone Sci. Eng. 2010, 32, 295-304. [CrossRef]

44. Kim, J.-G.; Yousef, A.E.; Khadre, M.A. Ozone and its current and future application in the food industry. Adv. Food Nutr. Res. 2003, 45, 167-218. [CrossRef] [PubMed]

45. Gorito, A.M.; Pesqueira, J.F.; Moreira, N.F.; Ribeiro, A.R.; Pereira, M.F.; Nunes, O.C.; Almeida, C.M.; Silva, A.M. Ozone-Based Water Treatment $\left(\mathrm{O}_{3}, \mathrm{O}_{3} / \mathrm{Uv}, \mathrm{O}_{3} / \mathrm{H}_{2} \mathrm{O}_{2}\right)$ for Removal of Organic Micropollutants, Bacteria Inactivation and Regrowth Prevention. J. Environ. Chem. Eng. 2021, 9, 105315. [CrossRef]

46. Nöthe, T.; Fahlenkamp, H.; von Sonntag, C. Ozonation of Wastewater: Rate of Ozone Consumption and Hydroxyl Radical Yield Environ. Sci. Technol. 2009, 43, 5990-5995. [CrossRef] [PubMed]

47. Ge, X.; Wang, X. Estimation of Freezing Point Depression, Boiling Point Elevation, and Vaporization Enthalpies of Electrolyte Solutions. Ind. Eng. Chem. Res. 2009, 48, 5123. [CrossRef]

48. Ginot, F.; Lenavetier, T.; Dedovets, D.; Deville, S. Solute strongly impacts freezing under confinement. Appl. Phys. Lett. 2020, 116, 253701. [CrossRef]

49. Collins, K.D.; Neilson, G.W.; Enderby, J.E. Ions in water: Characterizing the forces that control chemical processes and biological structure. Biophys. Chem. 2007, 128, 95-104. [CrossRef] [PubMed]

50. Sória, M.; Tavares, V.E.Q.; Pinto, M.A.B.; Stumpf, L.; Zarnott, D.; Bubolz, J.; Nörenberg, B.G. Evaluation of physicochemical water parameters in watersheds of southern Brazil. Ambient. Agua Interdiscip. J. Appl. Sci. 2020, 15, 1-11. [CrossRef]

51. Andreozzi, R.; Caprio, V.; Ermellino, I.; Insola, A.; Tufano, V. Ozone Solubility in Phosphate-Buffered Aqueous Solutions: Effect of Temperature,tert-Butyl Alcohol, and pH. Ind. Eng. Chem. Res. 1996, 35, 1467-1471. [CrossRef]

52. Vannini, A.; Canali, G.; Pica, M.; Nali, C.; Loppi, S. The Water Content Drives the Susceptibility of the Lichen Evernia prunastri and the Moss Brachythecium sp. to High Ozone Concentrations. Biology 2020, 9, 90. [CrossRef] [PubMed]

53. Silva, V.; Peirone, C.; Capita, R.; Alonso-Calleja, C.; Marques-Magallanes, J.; Pires, I.; Maltez, L.; Pereira, J.; Igrejas, G.; Poeta, P. Topical Application of Ozonated Oils for the Treatment of MRSA Skin Infection in an Animal Model of Infected Ulcer. Biology 2021, 10, 372. [CrossRef] [PubMed]

54. Dantas, A.D.S.; Day, A.; Ikeh, M.; Kos, I.; Achan, B.; Quinn, J. Oxidative Stress Responses in the Human Fungal Pathogen, Candida albicans. Biomolecules 2015, 5, 142-165. [CrossRef] [PubMed]

55. Ersoy, Z.G.; Barisci, S.; Dinc, O. Mechanisms of the Escherichia Coli and Enterococcus Faecalis Inactivation by Ozone. LWT 2019, 100, 306-313. [CrossRef]

56. World Health Organization. Who Guidelines on Hand Hygiene in Health Care: First Global Patient Safety Challenge: Clean Care is Safer Care; WHO: Geneva, Switzerland, 2010.

57. Larson, E.L.; Cronquist, A.B.; Whittier, S.; Lai, L.; Lyle, C.T.; Della Latta, P. Differences in skin flora between inpatients and chronically ill outpatients. Heart Lung 2000, 29, 298-305. [CrossRef] [PubMed]

58. Kim, J.-G.; Yousef, A.E.; Dave, S. Application of Ozone for Enhancing the Microbiological Safety and Quality of Foods: A Review. J. Food Prot. 1999, 62, 1071-1087. [CrossRef] [PubMed]

59. Inagaki, H.; Saito, A.; Sudaryatma, P.E.; Sugiyama, H.; Okabayashi, T.; Fujimoto, S. Rapid Inactivation of Sars-Cov-2 with Ozone Water. bioRxiv 2020. [CrossRef]

60. Shin, G.-A.; Sobsey, M.D. Reduction of Norwalk Virus, Poliovirus 1, and Bacteriophage MS2 by Ozone Disinfection of Water. Appl. Environ. Microbiol. 2003, 69, 3975-3978. [CrossRef] [PubMed]

61. Zhang, Y.; Wu, Q.; Zhang, J.; Yang, X.; Desk, S. Alteration in Escherichia coli and Streptococcus faecalis cells induced by ozone. SDRP J. Food Sci. Technol. 2017, 1. [CrossRef]

62. Komanapalli, I.R.; Lau, B.H. Inactivation of Bacteriophage Lambda, Escherichia Coli, and Candida Albicans by Ozone. Appl. Microbiol. Biotechnol. 1998, 49, 766-769. [CrossRef]

63. Moore, G.; Griffith, C.; Peters, A. Bactericidal Properties of Ozone and Its Potential Application as a Terminal Disinfectant. J. Food Prot. 2000, 63, 1100-1106. [CrossRef] [PubMed]

64. European Committee for Standardization. EN 1040-Basic Bactericidal Activity. UNE-EN 1040: 2006. Quantitative Suspension Test for the Evaluation of Basic Bactericidal Activity (Phase 1). Accredited by ENAC; European Committee for Standardization: Brussels, Belgium, 2006; Volume 44.

65. Ouf, S.A.; Moussa, T.A.; Abd-Elmegeed, A.M.; Eltahlawy, S.R. Anti-fungal potential of ozone against some dermatophytes. Braz. J. Microbiol. 2016, 47, 697-702. [CrossRef] [PubMed]

66. Mirmortazavi, A.; Haghi, H.R.; Fata, A.; Zarrinfar, H.; Bagheri, H.; Mehranfard, A. Kinetics of antifungal activity of homegenerated ozonated water on Candida albicans. Curr. Med. Mycol. 2018, 4, 27-31. [CrossRef]

67. Moger, G.; Khatri, I.; Kumar, N.A. Evaluation of effect of topical ozone therapy on salivary Candidal carriage in oral candidiasis. Indian J. Dent. Res. 2015, 26, 158-162. [CrossRef] [PubMed]

68. Zargaran, M.; Fatahinia, M.; Mahmoudabadi, A.Z. The efficacy of gaseous ozone against different forms of Candida albicans. Curr. Med. Mycol. 2017, 3, 26-32. [CrossRef] [PubMed]

69. Wigginton, K.R.; Kohn, T. Virus disinfection mechanisms: The role of virus composition, structure, and function. Curr. Opin. Virol. 2012, 2, 84-89. [CrossRef] [PubMed] 
70. Freitas-Silva, O.; Morales-Valle, H.; Venâncio, A. Potential of Aqueous Ozone to Control Aflatoxigenic Fungi in Brazil Nuts. ISRN Biotechnol. 2013, 2013, 1-6. [CrossRef] [PubMed]

71. Taubeneck, U.; Hugo, W.B. (Eds.) Inhibition and Destruction of the Microbial Cell. Xiii + 819 S., 47 Abb., 118 Tab; Academic Press: London, UK; New York, NY, USA, 1971.

72. Thanomsub, B.; Anupunpisit, V.; Chanphetch, S.; Watcharachaipong, T.; Poonkhum, R.; Srisukonth, C. Effects of ozone treatment on cell growth and ultrastructural changes in bacteria. J. Gen. Appl. Microbiol. 2002, 48, 193-199. [CrossRef]

73. Elvis, A.M.; Ekta, J.S. Ozone therapy: A clinical review. J. Nat. Sci. Biol. Med. 2011, 2, 66-70. [CrossRef] [PubMed]

74. Zhang, Y.; Wu, Q.; Zhang, J.; Yang, X. Effects of ozone on membrane permeability and ultrastructure in Pseudomonas aeruginosa. J. Appl. Microbiol. 2011, 111, 1006-1015. [CrossRef] [PubMed]

75. Alia, A.S.; Kholoud, K.H.A.-O. The effect of ozone on bacterial vaginosis and how it is affected by ultrastructural changes of cells by transmission electron microscope (TEM). Afr. J. Microbiol. Res. 2014, 8, 1060-1069. [CrossRef]

76. Patil, S.; Valdramidis, V.; Karatzas, K.A.G.; Cullen, P.; Bourke, P. Assessing the microbial oxidative stress mechanism of ozone treatment through the responses of Escherichia coli mutants. J. Appl. Microbiol. 2011, 111, 136-144. [CrossRef] [PubMed]

77. Tonus, S.S.; Oğuzkan, S.B.; Uğraş, H.I.; Kılıç, I.H. Determining the cytotoxic effect potential of ozonated hazelnut oil. Ozone Ther. 2018, 3. [CrossRef]

78. Bocci, V. Ozone as Janus: This controversial gas can be either toxic or medically useful. Mediat. Inflamm. 2004, 13, 3-11. [CrossRef] [PubMed]

79. Khan, S.A.; Seyam, O.; Smith, N.L.; Reid, I.; Gandhi, J.; Jiang, W. Clinical utility of ozone therapy for musculoskeletal disorders. Med. Gas. Res. 2018, 8, 103-110. [CrossRef] [PubMed]

80. Oliveira Junior, J.O.; Lages, G.V. Ozonioterapia Em Lombociatalgia. Rev. Dor 2012, 13, 261-270. [CrossRef]

81. Gavazza, A.; Marchegiani, A.; Rossi, G.; Franzini, M.; Spaterna, A.; Mangiaterra, S.; Cerquetella, M. Ozone Therapy as a Possible Option in COVID-19 Management. Front. Public Health 2020, 8, 417. [CrossRef]

82. Izadi, M.; Kheirjou, R.; Mohammadpour, R.; Aliyoldashi, M.H.; Moghadam, S.J.; Khorvash, F.; Jafari, N.J.; Shirvani, S.; Khalili, N. Efficacy of comprehensive ozone therapy in diabetic foot ulcer healing. Diabetes Metab. Syndr. Clin. Res. Rev. 2019, $13,822-825$. [CrossRef] [PubMed]

83. ANVISA, National Health Surveillance Agency. Identificação De Possível Caso De Candida Auris No Brasil. Available online: https:/ / www.gov.br/anvisa/pt-br/assuntos/noticias-anvisa/2020/identificacao-de-possivel-caso-de-candida-auris-nobrasil/ALERTA012020CANDIDAAURIS07.12.2020_2.pdf (accessed on 4 January 2021).

84. Alfouzan, W.; Dhar, R.; Albarrag, A.; Al-Abdely, H. The emerging pathogen Candida auris: A focus on the Middle-Eastern countries. J. Infect. Public Health 2019, 12, 451-459. [CrossRef] [PubMed]

85. Rutala, W.A.; Kanamori, H.; Gergen, M.F.; Sickbert-Bennett, E.E.; Weber, D.J. Susceptibility of Candida auris and Candida albicans to 21 germicides used in healthcare facilities. Infect. Control. Hosp. Epidemiology 2019, 40, 380-382. [CrossRef] [PubMed]

86. Cadnum, J.L.; Shaikh, A.A.; Piedrahita, C.T.; Sankar, T.; Jencson, A.L.; Larkin, E.L.; Ghannoum, M.A.; Donskey, C.J. Effectiveness of Disinfectants against Candida Auris and Other Candida Species. Infect. Control. Hosp. Epidemiol. 2017, 38, 1240-1243. [CrossRef] [PubMed]

87. Fu, L.; Le, T.; Liu, Z.; Wang, L.; Guo, H.; Yang, J.; Chen, Q.; Hu, J. Different efficacies of common disinfection methods against candida auris and other candida species. J. Infect. Public Health 2020, 13, 730-736. [CrossRef]

88. Livingston, S.; Cadnum, J.L.; Gestrich, S.; Jencson, A.L.; Donskey, C.J. Efficacy of automated disinfection with ozonated water in reducing sink drainage system colonization with Pseudomonas species and Candida auris. Infect. Control. Hosp. Epidemiol. 2018, 39, 1497-1498. [CrossRef] [PubMed]

89. Nogales, C.G.; Ferreira, M.B.; Montemor, A.F.; Rodrigues, M.F.D.A.; Lage-Marques, J.L.; Antoniazzi, J.H. Ozone therapy as an adjuvant for endondontic protocols: Microbiological-Ex vivo study and citotoxicity analyses. J. Appl. Oral Sci. 2016, 24, 607-613. [CrossRef] [PubMed] 